\title{
Antioxidant and immunomodulatory effect of AKSS16-LIV01 - a multi herbal formulation against ethanol induced liver dysfunction in mice
}

\author{
Soumendra Darbar ${ }^{1}$, Srimoyee Saha ${ }^{2}$, Kausikisankar Pramanik ${ }^{3}$ and Atiskumar Chattopadhyay ${ }^{1 *}$
}

\begin{abstract}
Background: Liver complication arises commonly due to high alcohol consumption rate. Majority of the people residing in both developed and under developed countries consuming alcohol face various liver complications such as liver fibrosis, fatty liver, liver cirrhosis and even hepatocellular carcinoma. Invention of safe and symptomatic medication to overcome this situation is a new challenge worldwide. The main objective of the study is to deliver a safe and symptomatic medication to reduce the ethanol induced liver dysfunction.

Methods: In this study we have developed a multi herbal formulation (AKSS-16-LIV01) which minimised liver damage against various toxicants. Swiss albino mice were divided into seven groups where ethanol induced damage was observed for weeks followed by sanative response observation by our herbal formulation. The groups are normal control group, ethanol treated group (50\% v/v), AKSS16-LIV01 low dose $(75 \mathrm{mg} / \mathrm{kg} /$ day) pre-treated group, AKSS16-LIV01 middle dose (150 mg/kg/day) pre-treated group, AKSS16-LIV01 high dose $(300 \mathrm{mg} / \mathrm{kg} / \mathrm{day})$ pre-treated group, Sylimarin pre-treated group (100 mg/kg/day) and only AKSS16-LIV01 (300 mg/kg/day) treated group.

Results: The results potrayed significant elevation of various biochemical parameters, lipid profile parameters, lipid peroxidation, nitric oxide (NO) concentration, nitric oxide synthase level and pro inflammatory cytokines level i.e. tumor necrosis factor (TNF- $\alpha$ ) and transforming growth factor (TGF- $\beta 1$ ) in the ethanol induced mice. On the other hand serum total protein, total albumin, albumin globulin ratio and level of tissue antioxidant enzymes activity (SOD, CAT, GSH and GPx) were significantly reduced by ethanol. Dose depended therapeutic application of the formulation (AKSS16-LIV01) significantly suppressed all the relevant above parameters and protected the liver from ethanol induced fibrogenesis. Apart from this gross morphology of the liver, H\&E liver histology and massontrichrome\&serius red examination of the liver section strongly supported the hepatoprotive effect of the formulation as compared with standard drug Sylimarin. Result of the study implies that developed multi herbal formulation (AKSS16-LIV01) at a dose of $300 \mathrm{mg} / \mathrm{kg} /$ day gave the best optimum response to reduce the ethanol intoxication.
\end{abstract}

Conclusion: Result clearly depict that AKSS16-LIV01 may be a safe and nontoxic medication which protect the liver against ethanol induced oxidative injury and maintained pro inflammatory cytokines level in the future.

Keywords: Multi herbal formulation, Liver damage, Liver function test, Lipid profile, Oxidative stress, Liver histology

\footnotetext{
* Correspondence: atischatterjee@gmail.com

${ }^{1}$ Faculty of Science, Jadavpur University, Raja S C Mallick Road, Kolkata, West Bengal 700032 , India

Full list of author information is available at the end of the article
}

\section{Springer Open}

(c) The Author(s). 2021 Open Access This article is licensed under a Creative Commons Attribution 4.0 International License, which permits use, sharing, adaptation, distribution and reproduction in any medium or format, as long as you give appropriate credit to the original author(s) and the source, provide a link to the Creative Commons licence, and indicate if changes were made. The images or other third party material in this article are included in the article's Creative Commons licence, unless indicated otherwise in a credit line to the material. If material is not included in the article's Creative Commons licence and your intended use is not permitted by statutory regulation or exceeds the permitted use, you will need to obtain permission directly from the copyright holder. To view a copy of this licence, visit http://creativecommons.org/licenses/by/4.0/. 


\section{Introduction}

Our body continuously exposed with various harmful toxicants as a result liver detoxifying the toxicant and maintains cellular homeostasis $[1,2]$. People in both developed and underdeveloped countries when consume excesses alcohol or taken alcohol on a continuous basis leading to alcoholic liver disease (ALD). Individuals those are suffering with ALD facing lots of liver complications such as fatty liver disease, hepatic fibrosis, hepatic cirrhosis and hepatic cellular carcinoma even death $[3,4]$. World health organization (WHO) published a report that stated death due to the liver failure stands the fifth position after cancer, cardiac failure, nervous disorder and respiratory infection [5]. Scientific study stated that consumption of ethanol elevate the ratio of $\mathrm{NADH} / \mathrm{NAD}^{+}$in the liver cell which create disruption of oxidation of fatty acids in mitochondria developed liver dysfunction [6, 7]. Other causes of liver disease deposition of lipid molecule in the liver cells which stop the normal hepatic functions. Alcohol enhances the transportation process of lipids towards the liver from the small intestine which elevate the fatty acids mobilization from adipose tissue, taken up by the liver [8]. This causes damage of the liver cell membrane which releases the transaminases enzymes (AST and ALT) in the blood stream. On the other hand this damaged cell membrane also release alkaline phosphatase (ALP) and gamma glutamyltransferase (GGT) which indicate hepatic damage and inhibit the intercellular homeostasis [9-12].

Superoxide $\left(\mathrm{O}_{2}^{-}\right)$, hydroxyl radical (.OH), hydroxyl ion $\left(\mathrm{OH}^{-}\right)$and hydrogen peroxide $\left(\mathrm{H}_{2} \mathrm{O}_{2}\right)$ are the common reactive oxygen species (ROS) were generated in the liver cell [13] when exposed with certain chemicals, environmental pollutants, xenobiotics etc. Firstly, these free radicals are generated from the oxidation procedure within the cell developed oxidative stress which destabilizes the normal cellular homeostasis $[14,15]$. Secondly, Chronic intake of alcohol generates ROS via cytochrome P450 2E1 in the liver cell producing DNA damage, loss of membrane integrity, amino acid oxidation and inactivation of specific enzymes through oxidation of their cofactors [16, 17]. Important antioxidant enzymes like super oxide dismutase (SOD), catalase (CAT), glutathione (GSH) and glutathione peroxidase (GPx) mainly converts these harmful radicals through a series of biochemical reaction into oxygen and water molecule and protect the hepatic cell from the oxidative stress injury. It is evident that excessive intake of alcohol may develop cellular oxidative stress; indirectly disrupting cellular antioxidant defense system, which eventually produces cell death (apoptosis) and tissue damage. On the other hand nitric oxide $(\mathrm{NO})$ is an important mediator of many physiological functions responsible for pathogenesis of many diseases. Chronic alcohol consumption increases nitric oxide (NO) levels which may lead to toxicity by peroxynitrite and destroy the membranous integrity. Free radicals i.e. reactive oxygen species (ROS) and reactive nitrogen species (RNS) when generates excessively in cell may not be neutralized in the system and cannot be eliminated from the body [18].

From the ancient time people from various countries depends on traditional system of medicine for curing the diseases as a safe and symptomatic medications. In the modern world Indian medicinal herbs and medicinal spices have been extensively used as an alternative medicine because of their promising medicinal property and lesser side effects in comparison to the allopathic drugs [19]. These medicinal herbs and spices are enriched with various constituents likes polyphenols, flavonoids, alkaloids, glycosides, tannins, proteins, amino acids, saphonin etc., which play a key role in cellular protection from the toxicants. Herbal formulations composed of some medicinally sound plants, now have garnered greater interest throughout the world due to its synergistic action. Recently people have a greater interest in herbal medicines because of their lesser side effect in clinical experience, pronounced effectiveness, safe for long term use and relatively low cost [20-22].

Currently throughout the globe fight against various liver dysfunctions such as fatty liver, liver fibrosis, liver cirrhosis etc. through symptomatic and safe medication is a new challenge. Presently, there is no effective treatment for hepatic dysfunctions. These herbs are natural resources of antioxidants that serve as the first line of defense against free radical damage and are considered to be important in maintaining optimum health and hygiene. Our previous reports stated that the formulation have no adverse side effect and no toxicity in mice [23, 24]. So, in the present study we formulated a new novel phytomedicine (AKSS16-LIV01) composed of six indigenous medicinal herbs and three medicinal spices those were mentioned in Ayurveda. Commercially available formulations composed of more than 12 medicinal herbs without medicinal spices. On the other hand in composition of the formulation the concentration of the individual herbs is less in comparison to marketed products. So, the developed formulation is an unique one and produced better therapeutic effects on animal models. Therefore, the present study was undertaken to evaluate the ethanol induced oxidative stress and hepatic injury of adult mice and its deleterious recovery by the application of unique novel multi herbal formulation (AKSS16LIV01). The results of this study are expected to supply a transparent picture about the role of our newly formulated AKSS16-LIV01 in ethanol-induced hepatic damage, and should shed light on an achievable ethno-botany driven solution for serious liver problems. 


\section{Materials and methods}

\section{Chemicals}

Trichloroacetic acid (TCA), thiobarbituric acid (TBA), ethanol, TRIS buffers were purchased from SISCO laboratories, India. PBS buffer ( $\mathrm{pH} 7.2)$ was taken from Sigma-Aldrich, Germany. All the biochemical kits (ALT, AST, GGT, ALP, Cholesterol, Triglyceride, Phospholipid, HDL, LDL etc.) were procured from Span Diagnostic, Surat, India. Hydroxyproline assay kit was procured from Bio Vision, Milpitas, CA. Antioxidant kits (SOD, CAT, GSH and GPx) were obtained from Boehringer, USA. ELISA kit TNF- $\alpha$ and TGF- $\beta_{1}$ were procured from Sigma Aldrich, USA. All others reagents utilized in this study are laboratory grade.

\section{Collection and authentication of the herbs}

In this study all the required medicinal herbs and medicinal species used for the preparation of novel formulation were collected from registered (authorized by West Bengal AYUSH department) medicinal herbs supplier. The plants and spices were identified and authenticated by renounced taxonomist, department of Pharmaceutical Technology, Jadavpur University, Kolkata, India and properly kept as voucher specimen (Table 1). The plants and plant parts used in extract preparation are listed in Table 2.

\section{Preparation of extract}

At the onset of the experiment collected plants and spices were cleaned by double distilled water until and unless those are properly cleaned. The cleaned spices and plants were air dried through normal temperature under sunlight. After that the samples were kept in calibrated and validated hot air oven at $75{ }^{\circ} \mathrm{C}$ for $20 \mathrm{~min}$ and $55^{\circ} \mathrm{C}$ for $30 \mathrm{~min}$. To obtain fine powder the plant parts and the spices were ground by a blade mill. A standard established protocol was followed for the preparation of extract with slight modification. After collection of the final extract, it was stored at $4{ }^{\circ} \mathrm{C}$ for further use. The extract was prepared with the ratio of $2: 2: 5: 5: 5: 2: 1: 1: 1$ based on the individual plants ingredients. Individual yield of the each extract were Tinospora sinensis (Lour.) Merr. 11.80\%, Terminalia chebula Retz. 10.52\%, Azadirachta indica A. Juss. 9.75\%, Andrographis paniculata (Burm.f.) Nees 12.52\%, Aloe barbadensis Mill. 11.48\%, Curcuma longa L. 14.06\%, Trigonella foenum-graecum L. 15.05\%, Piper nigrum L. $13.60 \%$ and Elettaria cardamomum (L.) Maton $12.64 \%$. After the final collection of the working extract we obtained $92 \%$ of the plant extract which is commercially sound.

\section{Preparation of Tinospora cordifolia extract}

The plants were collected, identified and authenticated by an experienced botanist. Then the plants were cleaned with double distilled water and dried under sunlight. The plants were kept in a hot air oven at $75^{\circ} \mathrm{C}$ for $20 \mathrm{~min}$ and $55^{\circ} \mathrm{C}$ for $30 \mathrm{~min}$. Two hundred grams of Tinospora cordifolia powder were mixed with $1200 \mathrm{ml}$ methanol and sonicated for $30 \mathrm{~min}$ using an ultrasonic bath at room temperature, centrifuged at $3000 \mathrm{rpm}$ for $15 \mathrm{~min}$ and the supernatant was collected, process repeated four times, finally supernatant was evaporated under reduced pressure at $35^{\circ} \mathrm{C}$ in a rotary evaporator. Three milliliters of methanol was used to reconstitute the residue. The extract was filtered using Whatman filter paper and kept at $4{ }^{\circ} \mathrm{C}$ for further use. The percentage yield of the extract is $11.80 \%$.

\section{Preparation of Terminalia chebula extract}

The collected plants were identified and authenticated by a well-known botanist. Plants were cleaned with double distilled water. After that the sample was dried under sunlight. The plants were kept in a hot air oven at $75^{\circ} \mathrm{C}$ for $20 \mathrm{~min}$ and $55^{\circ} \mathrm{C}$ for $30 \mathrm{~min}$. Two hundred grams of Terminalia chebula powder were mixed with $1200 \mathrm{ml}$ methanol and sonicated for $30 \mathrm{~min}$ using an ultrasonic bath at room temperature, centrifuged at $3000 \mathrm{rpm}$ for $15 \mathrm{~min}$ and the supernatant was collected, process repeated four times, finally supernatant was evaporated under reduced pressure at $35^{\circ} \mathrm{C}$ in a rotary

Table 1 List of ingredients and their voucher specimen number

\begin{tabular}{|c|c|c|}
\hline SI. No. & Plant Ingredients & Voucher specimen number \\
\hline 1. & Tinospora sinensis (Lour.) Merr. & $J U / A K C / 16 / 151$ \\
\hline 2. & Terminalia chebula Retz. & JU/AKC/16/152 \\
\hline 3. & Azadirachta indicaA.Juss. & JU/AKC/16/153 \\
\hline 4. & Andrographis paniculata (Burm.f.) Nees & JU/AKC/16/154 \\
\hline 5. & Aloe barbadensis Mill. & JU/AKC/16/155 \\
\hline 6. & Curcuma longa to Curcuma longa L. & JU/AKC/16/156 \\
\hline 7. & Trigonella foenum-graecum $\mathrm{L}$. & JU/AKC/16/157 \\
\hline 8. & Piper nigrum to Piper nigrum L. & JU/AKC/16/158 \\
\hline 9. & Elettaria cardamomum (L.) Maton & JU/AKC/16/159 \\
\hline
\end{tabular}


Table 2 Composition of ingredient(s) present in AKSS16-LIV01

\begin{tabular}{|c|c|c|c|c|c|}
\hline SI No. & Botanical Name & Common Name & Family & Part Used & $\begin{array}{l}\text { Quantity used } \\
\text { in extract }^{a}\end{array}$ \\
\hline 1. & Tinospora sinensis (Lour.) Merr. & Guduchi & Menispermaceae & Stem & $20 \mathrm{mg}$ \\
\hline 2. & Terminalia chebula Retz. & Haritaki & Combretaceae & Fruit & $20 \mathrm{mg}$ \\
\hline 3. & Azadirachta indicaA.Juss. & Neem & Meliaceae & Leaves & $50 \mathrm{mg}$ \\
\hline 4. & Andrographis paniculata (Burm.f.) Nees & Kalmegh & Acanthaceae & Leaves \&Steam & $50 \mathrm{mg}$ \\
\hline 5. & Aloe barbadensis Mill. & Aloevera & Liliaceae & Leaves \&Steam & $50 \mathrm{mg}$ \\
\hline 6. & Curcuma longa to Curcuma longa $\mathrm{L}$. & Curcuma,Haldi & Zingiberales & Rhizome & $20 \mathrm{mg}$ \\
\hline 7. & Trigonella foenum-graecum $\mathrm{L}$. & Methi & Fabaceae & Seed & $10 \mathrm{mg}$ \\
\hline 8. & Piper nigrum to Piper nigrum L. & Blackpepper & Piperaceae & Seed & $10 \mathrm{mg}$ \\
\hline 9. & Elettaria cardamomum (L.) Maton & Cardamom & Zingiberaceae & Seed & $10 \mathrm{mg}$ \\
\hline
\end{tabular}

${ }^{\mathrm{a}}$ Amount required for preparation of $5 \mathrm{ml}$ extract

evaporator. Three milliliters of methanol was used to reconstitute the residue. The extract was filtered using Whatman filter paper and kept at $4{ }^{\circ} \mathrm{C}$ for further use. The percentage yield of the extract is $10.52 \%$.

\section{Preparation of Azadirachta indica extract}

Azadirachta indica was collected, identified and authenticated by an experienced botanist. Then the plants were cleaned with double distilled water and dried under sunlight. The plants were kept in a hot air oven at $75^{\circ} \mathrm{C}$ for $20 \mathrm{~min}$ and $55^{\circ} \mathrm{C}$ for $30 \mathrm{~min}$. Five hundred grams of Azadirachta indica powder were mixed with $1200 \mathrm{ml}$ methanol and sonicated for $30 \mathrm{~min}$ using an ultrasonic bath at room temperature, centrifuged at $3000 \mathrm{rpm}$ for $15 \mathrm{~min}$ and the supernatant was collected, process was repeated four times, finally supernatant was evaporated under reduced pressure at $35^{\circ} \mathrm{C}$ in a rotary evaporator. Three milliliters of methanol was used to reconstitute the residue. The extract was filtered using Whatman filter paper and kept at $4{ }^{\circ} \mathrm{C}$ for further use. The percentage yield of the extract is $9.75 \%$.

\section{Preparation of Andrographis paniculata extract}

The plants were collected, identified and authenticated by a experienced botanist. Then the plants were cleaned with double distilled water and dried under sunlight. The plants were kept in a hot air oven at $75^{\circ} \mathrm{C}$ for $20 \mathrm{~min}$ and $55^{\circ} \mathrm{C}$ for $30 \mathrm{~min}$. Five hundred grams of Andrographis paniculata powder were mixed with $1200 \mathrm{ml}$ methanol and sonicated for $30 \mathrm{~min}$ using an ultrasonic bath at room temperature, centrifuged at $3000 \mathrm{rpm}$ for $15 \mathrm{~min}$ and the supernatant was collected, process was repeated four times, finally supernatant was evaporated under reduced pressure at $35^{\circ} \mathrm{C}$ in a rotary evaporator. Three milliliters of methanol was used to reconstitute the residue. The extract was filtered using Whatman filter paper and kept at $4{ }^{\circ} \mathrm{C}$ for further use. The percentage yield of the extract is $12.52 \%$.

\section{Preparation of Aloe barbadensis miller extract}

The plants were collected, identified and authenticated by an experienced botanist. Then the plants were cleaned with double distilled water and dried under sunlight. The plants were kept in a hot air oven at $75^{\circ} \mathrm{C}$ for $20 \mathrm{~min}$ and $55^{\circ} \mathrm{C}$ for $30 \mathrm{~min}$. Five hundred grams of Aloe barbadensis miller powder were mixed with $1200 \mathrm{ml}$ methanol and sonicated for $30 \mathrm{~min}$ using an ultrasonic bath at room temperature, centrifuged at $3000 \mathrm{rpm}$ for $15 \mathrm{~min}$ and the supernatant was collected, process repeated four times, finally supernatant was evaporated under reduced pressure at $35^{\circ} \mathrm{C}$ in a rotary evaporator. Three milliliters of methanol was used to reconstitute the residue. The extract was filtered using Whatman filter paper and kept at $4{ }^{\circ} \mathrm{C}$ for further use. The percentage yield of the extract is $11.48 \%$.

\section{Preparation of Curcuma longa extract}

The plants were collected, identified and authenticated by a experienced botanist. Then the plants were cleaned with double distilled water and dried under sunlight. The plants were kept in a hot air oven at $75^{\circ} \mathrm{C}$ for $20 \mathrm{~min}$ and $55^{\circ} \mathrm{C}$ for $30 \mathrm{~min}$. Two hundred grams of Curcuma longa powder were mixed with $1200 \mathrm{ml}$ methanol and sonicated for $30 \mathrm{~min}$ using an ultrasonic bath at room temperature, centrifuged at $3000 \mathrm{rpm}$ for $15 \mathrm{~min}$ and the supernatant was collected, process repeated four times, finally supernatant was evaporated under reduced pressure at $35^{\circ} \mathrm{C}$ in a rotary evaporator. Three milliliters of methanol was used to reconstitute the residue. The extract was filtered using Whatman filter paper and kept at $4{ }^{\circ} \mathrm{C}$ for further use. The percentage of yield of the extract is $14.06 \%$.

\section{Preparation of Trigonella foenum-graecum extract}

The plants were collected, identified and authenticated by an experienced botanist. Then the plants were cleaned with double distilled water and dried under sunlight. The plants were kept in a hot air oven at $75^{\circ} \mathrm{C}$ for 
$20 \mathrm{~min}$ and $55^{\circ} \mathrm{C}$ for $30 \mathrm{~min}$. One hundred grams of Trigonella foenum-graecum powder were mixed with $1200 \mathrm{ml}$ methanol and sonicated for $30 \mathrm{~min}$ using an ultrasonic bath at room temperature, centrifuged at $3000 \mathrm{rpm}$ for $15 \mathrm{~min}$ and the supernatant was collected, process repeated four times, finally supernatant was evaporated under reduced pressure at $35^{\circ} \mathrm{C}$ in a rotary evaporator. Three milliliters of methanol was used to reconstitute the residue. The extract was filtered using Whatman filter paper and kept at $4{ }^{\circ} \mathrm{C}$ for further use. The percentage yield of the extract is $15.05 \%$.

\section{Preparation of Piper nigrum extract}

The plants were collected, identified and authenticated by an experienced botanist. Then the plants were cleaned with double distilled water and dried under sunlight. The plants were kept in a hotairovenat $75^{\circ} \mathrm{C}$ for 20 min and $55^{\circ} \mathrm{C}$ for $30 \mathrm{~min}$. One hundred grams of Piper nigrum powder were mixed with $1200 \mathrm{ml}$ methanol and sonicated for $30 \mathrm{~min}$ using an ultrasonic bath at room temperature, centrifuged at $3000 \mathrm{rpm}$ for $15 \mathrm{~min}$ and the supernatant was collected, process repeated four times, finally supernatant was evaporated under reduced pressure at $35^{\circ} \mathrm{C}$ in a rotary evaporator. Three milliliters of methanol was used to reconstitute the residue. The extract was filtered using Whatman filter paper and kept at $4{ }^{\circ} \mathrm{C}$ for further use. The percentage yield of the extract is $13.60 \%$.

\section{Preparation of Elettaria cardamomum extract}

The plants were collected, identified and authenticated by an experienced botanist. Then the plants were cleaned with double distilled water and dried under sunlight. The plants were kept in a hot air oven at $75^{\circ} \mathrm{C}$ for $20 \mathrm{~min}$ and $55^{\circ} \mathrm{C}$ for $30 \mathrm{~min} .100 \mathrm{gmo}$ of Elettaria cardamomum powder were mixed with $1200 \mathrm{ml}$ methanol and sonicated for $30 \mathrm{~min}$ using an ultrasonic bath at room temperature, centrifuged at $3000 \mathrm{rpm}$ for $15 \mathrm{~min}$ and the supernatant was collected, process was repeated four times, finally supernatant was evaporated under reduced pressure at $35^{\circ} \mathrm{C}$ in a rotary evaporator. Three milliliters of methanol was used to reconstitute the residue. The extract was filtered using Whatman filter paper and kept at $4{ }^{\circ} \mathrm{C}$ for further use. The percentage yield of the extract is $12.64 \%$.

\section{Phytochemical screening}

Various essential plant secondary metabolites such as sterols and triterpenes, $\mathrm{Mg}^{2+}$ turning test of flavonoids, alkaloids, saponins, glycosides, tannins, phenolic content, total flavonoids content in the developed multi-herbal formulation (AKSS16-LIV01) were detected through quantitative analysis with slight modification as described by Evans and Gueverra [25-27]. Detailed procedure as follows:

\section{Test for tannins}

$0.30 \mathrm{~g}$ grinding powder sample was weighed into a test tube and boiled for $10 \mathrm{~min}$ in a water bath containing $30 \mathrm{ml}$ of water. Standard filter paper was used for filtration. To $5 \mathrm{ml}$ of the filtrate was added 3 drops of $0.1 \%$ ferric chloride. A brownish green or a blue black colouration showed positive test [28].

\section{Test for Saponin}

Distilled water $(30 \mathrm{ml})$ was added to grinding powder samples $(0.30 \mathrm{~g})$ and boiled for $10 \mathrm{~min}$ in a water bath and filtered using Whatman filter paper number 42 $(125 \mathrm{~mm})$. A mixture of distilled water $(5 \mathrm{ml})$ and filtrate $(10 \mathrm{ml})$ was agitated vigorously for a stable persistent froth. The formation of emulsion on addition of three drops of olive oil showed positive result [29].

\section{Test for steroid}

Weighed $0.03 \mathrm{~g}$ sample into a beaker was mixed with 20 $\mathrm{ml}$ of ethanol; the component was extracted for $2 \mathrm{~h}$. Five milliliters of plant extract (ethanolic) was taken and $2 \mathrm{ml}$ acetic anhydride added within it. After that $2 \mathrm{ml}$ of concentrated tetraoxosulphate (VI) acid was added to obtained the colour. A violet to blue or rather bluish green colour change in sample(s) indicated the presence of steroids [30].

\section{Test for Terpenoids}

Powder sample $(0.30 \mathrm{~g})$ was weighed into a beaker with $30 \mathrm{ml}$ ethanol and component extracted for $2 \mathrm{~h}$. Two milliliters of chloroform and $3 \mathrm{ml}$ of concentrated tetraoxosulphate (VI) acid was taken and mixed vigorously. Then added $5 \mathrm{ml}$ of plant extract to it. A reddish brown colour in the sample indicates the positive results and presence of terpenoids [31].

\section{Test for flavonoids}

$0.30 \mathrm{~g}$ powder was taken in a cleaned beaker and added $30 \mathrm{ml}$ of distilled water. The mixture was stayed for $2 \mathrm{~h}$ and filtered with standard filter paper number. Ten milliliters of the filtrate extract (aqueous) was taken and $5 \mathrm{ml}$ of $1.0 \mathrm{M}$ dilute ammonia solution added to it. After that $5 \mathrm{ml}$ of concentrated tetraoxosulphate (VI) acid was added. Appearance of yellow colouration which disappeared on standing shows the presence of flavonoids [32].

\section{Test for alkaloids}

Two grams powder sample was in a cleaned conical flask for extraction by using $5 \%$ tetraoxosulphate (VI) acid $\left(\mathrm{H}_{2} \mathrm{SO}_{4}\right)(20 \mathrm{ml})$ in $50 \%$ ethanol by boiling for $2 \mathrm{~min}$ and 
filtered through Whatman filter paper. The filtrate was made alkaline using $5 \mathrm{ml}$ of $28 \%$ ammonia solution $\left(\mathrm{NH}_{3}\right)$ in a separating funnel. Two sets of chloroform $(5.0 \mathrm{ml})$ was for further solution extraction where chloroform solution was extracted with two $5 \mathrm{ml}$ portions of $1.0 \mathrm{M}$ dilute tetraoxosulphate (VI) acid. This final acid extract was then accustomed perform the subsequent test: zero. $5 \mathrm{ml}$ of Dragendorff's chemical agent (Bismuth iodide solution) was mixed with $2 \mathrm{ml}$ of acid extract and precipitated orange color infers the presence of organic compound [33].

\section{Test for glycoside}

To $2.00 \mathrm{~g}$ of sample $20 \mathrm{ml}$ of water was supplementary, heated for $5 \mathrm{~min}$ on a water bathtub and filtered through Gem paper $(12.5 \mathrm{~cm})$. The subsequent tests were administrated with the filtrate: (a) zero. $2 \mathrm{ml}$ of Fehling's solutions $\mathrm{A}$ and $\mathrm{B}$ was mixed with $5 \mathrm{ml}$ of the filtrate till it became base-forming (tested with acid-base indicator paper). A brick-red colouration on heating showed a positive result. (b) Instead of water, $15 \mathrm{ml}$ of $1.0 \mathrm{M}$ sulphuric acid was used to repeat the above test and the quantity of precipitate obtained compared with that of (a) above. High precipitate content indicated the presence of glycoside while low content showed the absence of glycoside [34].

\section{Test for phenolic content}

One milliliter of plant sample was taken in a test tube few drops of $10 \%$ ferric chloride solution was added to it. Violet colour appeared which indicated the presence of phenolic compounds [35].

\section{Animals}

Adult male swiss albino mice weighing $26 \mathrm{~g} \pm 3 \mathrm{~g}$ were obtained from our CPCSEA registered central animal house facility. The animals were divided into seven experimental groups with 10 animals in each group. For acclimatization mice were kept in the environment controlled animal room for 1 week before the onset of the experiment. The animals were maintained at $12 \mathrm{~h}$ light/dark cycle with constant temperature $\left(22 \pm 2{ }^{\circ} \mathrm{C}\right)$ and humidity $(54 \pm 4 \%)$. Standard pellet diets (Procure from Hind liver India Limited, Mumbai) were given to the animal with and water ad libitum. The whole experimental procedure were carried out according to the new revised guidelines (2018) of CPCSEA, Ministry of Agricultural and Animal Husbandry, Govt. of India, New Delhi and approved by the Institutional Animal Ethics Committee (IAEC), Jadavpur University having approval number (IAEC/PHARM/1503/03/ 2019 dated 30.11.19).

\section{Experimental protocol}

Swiss albino mice were divided into seven groups where ethanol induced damage was observed for weeks followed by sanative response observation by our herbal formulation. The groups are normal control group, ethanol treated group $(50 \% \mathrm{v} / \mathrm{v})$, AKSS16-LIV01 low dose (75 mg/kg/day) pre-treated group, AKSS16-LIV01 middle dose $(150 \mathrm{mg} / \mathrm{kg} /$ day $)$ pre-treated group, AKSS16LIV01 high dose $(300 \mathrm{mg} / \mathrm{kg} /$ day $)$ pre-treated group, Sylimarin pre-treated group $(100 \mathrm{mg} / \mathrm{kg} /$ day $)$ and only AKSS16-LIV01 (300 mg/kg/day) group. A detail of the protocol was given in Table 3.

\section{Body weight gains and feed efficiency}

Routine body weights of the each animal were measured and recorded in every week from the initial day to the final day of experiment and then determined the body weight alteration. Regular food consumption was calculated by measuring food residue on the basis food given at the fix time. Feed conversion was obtained by dividing total feed intake by weight gain.

\section{Blood collection}

After the experimental period $200 \mu \mathrm{L}$ of blood sample were collected into micro-centrifuge tubes with and without EDTA (2\%) from the retro orbital plexus of the mice. Blood collected from animals were taken in heparinized tube. The tubes were stay for $3 \mathrm{~h}$ in $45^{\circ}$ angle at room temperature $\left(27^{\circ} \mathrm{C}\right)$. After that the blood samples were centrifuged at $3500 \mathrm{~g}$ for $15 \mathrm{~min}$ to obtained serum. Developed light yellow colour serum was collected with caution and stored $-4{ }^{\circ} \mathrm{C}$ for further biochemical analysis.

Table 3 Experimental Design

\begin{tabular}{|c|c|}
\hline Groups & Treatment \\
\hline I & $\begin{array}{l}\text { Normal control received only the vehicle }(1 \mathrm{ml} / \mathrm{kg} \text { olive oil } \\
\text { twice a week for } 8 \text { weeks) }\end{array}$ \\
\hline$\|$ & Received Ethanol (50\% v/v) daily for 8 weeks \\
\hline III & $\begin{array}{l}\text { Treatment with ethanol }(50 \% \mathrm{v} / \mathrm{v}) \text { for } 4 \text { weeks and then } \\
\text { pre-treated with herbal formulation AKSS16-LIV01 } \\
(75 \mathrm{mg} / \mathrm{kg} \text { bw/day) for next } 4 \text { weeks }\end{array}$ \\
\hline IV & $\begin{array}{l}\text { Treatment with ethanol (50\% v/v) for } 4 \text { weeks and then } \\
\text { pre-treated with herbal formulation AKSS16-LIV01 } \\
(150 \mathrm{mg} / \mathrm{kg} \text { bw/day) for next } 4 \text { weeks }\end{array}$ \\
\hline V & $\begin{array}{l}\text { Treatment with ethanol (50\% v/v) for } 4 \text { weeks and then } \\
\text { pre-treated with herbal formulation AKSS16-LIV01 } \\
(300 \mathrm{mg} / \mathrm{kg} \text { bw/day) for next } 4 \text { weeks }\end{array}$ \\
\hline $\mathrm{VI}$ & $\begin{array}{l}\text { Treatment with ethanol ( } 50 \% \text { v/v) for } 4 \text { weeks and then } \\
\text { pre-treated with Silymarin standard hepatoprotective } \\
\text { drug at a dose }(100 \mathrm{mg} / \mathrm{kg} \mathrm{bw}) \text { for next } 4 \text { weeks }\end{array}$ \\
\hline VII & $\begin{array}{l}\text { Treated with multi herbal formulation (MHF) } \\
\text { AKSS16-LIV01 ( } 300 \mathrm{mg} / \mathrm{kg} \mathrm{bw/day} \mathrm{all} \mathrm{over} \mathrm{the} \\
\text { experiment). }\end{array}$ \\
\hline
\end{tabular}




\section{Hematological parameters}

Blood samples were taken from the retro orbital plexus of experimental mice and collected in heparinized tubes for determination of haematological parameters. Blood parameters were studied in this experiment i.e. haemoglobin $(\mathrm{Hb})$, mean corpuscular volume (MCV), reticulocyte, hematocrit, mean corpuscular hemoglobin concentration $(\mathrm{MCHC})$, total red blood cell (TRBC), mean corpuscular hemoglobin $(\mathrm{MCH})$, total white blood cell (TWBC), platelets, and differential count using Sysmax-K1000 automatic Cell Counter.

\section{Assessment of liver function parameters}

All biochemical tests were carried out by using commercial kits with little modification of manufactures instruction. Liver function test (LFT) parameters like different aminotransferase (AST \& ALT), [36, 37] alkaline phosphatase (ALP), [38] gamma-glutamyl transferase (GGT), [39] globulin, [40] bilirubin (total \& direct) [41] were analysed using biochemical assay kits (Merck, India) with manufacturer's instruction. Total protein concentration was determined in the serum by the method of Lowry et al. [42].

\section{Assessment of serum lipid profile}

Serum lipid profile like Cholesterol, [43] Triglyceride, [44] Phospholipids, [45] Free fatty acids, [46] LDLcholesterol [47] and HDL-cholesterol [48] were measured using enzymatic calorimetric kits (ELITech Diagnostic, France) according to manufacture instructions.

\section{Preparation of tissue homogenate}

Prior to tissue biochemical analysis, $100 \mathrm{mg} / \mathrm{mL}$ of whole liver was homogenized in $50 \mathrm{mM}$ phosphate buffer $(\mathrm{pH}$ 7.0). After homogenization the homogenate was centrifuged at $11000 \mathrm{rpm}$ for 12 mins and the supernatant was collected and used for different parameters. Protein concentrations of liver supernatant were determined [49] using commercially available kit (Span Diagnostics Ltd., India) following procedure prescribed by manufacturer.

\section{Hydroxyproline assay}

Hydroxyproline assay to quantify collagen content were performed by established protocol. In details, $10 \mathrm{mg}$ of freshly collected liver was homogenized in $100 \mathrm{ml}$ of sterile MQ water followed by hydrolysis in $12 \mathrm{~N} \mathrm{HCl}$ $(100 \mathrm{ml})$ at $120^{\circ} \mathrm{C}$. Four hours later $5 \mathrm{ml}$ of tissue lysate became transferred to a 96-well plate. The whole sample was incubated at $37^{\circ} \mathrm{C}$ for $18 \mathrm{~h}$ to evaporate the acid. Test Samples have been incubated with including equal amounts of chloramine $\mathrm{T}$ and Ehrlich's reagents for 40 min at $70^{\circ} \mathrm{C}$. Absorbance was recorded at $560 \mathrm{~nm}$ by using an ELISA plate reader (Synergy BioTek, Winooski,
VT). Three to five $\mathrm{mL}$ blood sample was required to conduct the whole study.

\section{Assessment of lipid peroxidation, NO and iNOS}

The level of lipid peroxidation (MDA content) was measured from tissue sample and serum sample according to the method of Ohkawa [50] with slight modification. The level of NO and iNOS activity were determined from the liver homogenate through ELISA method using the commercial kit [51]. The detailed methods are as follows:

\section{Lipid peroxidation (LPO)}

The measurement was carried out using lipid peroxidation (MDA) assay kit (Sigma-aldrich Ltd., UK) in accordance to the manufacturer's instructions. Here lipid peroxidation is determined by the reaction of malondialdehyde (MDA) with thiobarbituric acid (TBA) as a reactor to form a colouring product, proportional to the MDA present. To form the MDA-TBA adduct, the TBA solution $(600 \mathrm{~mL})$ was added into each sample and incubated at $95^{\circ} \mathrm{C}$ for $60 \mathrm{~min}$, after cooling to room temperature in an ice bath for $10 \mathrm{~min}$. Two hundred milliliters of each mixture was transferred into a 96-well plate for analysis. The absorbance was measured at 532 nm [50].

\section{NO activity}

Nitrite is estimated through established "Griess Reaction" method. In this method, two-step diazotization reaction during which acidified $\mathrm{NO}^{2-}$ produces a nitrosating agent, which chemically reacts with sulphanilic acid to supply the diazonium ion. This ion is then coupled to $\mathrm{N}$-(1-naphthyl) ethylenediamine [NEDD] to make the chromophoric azo-derivative which absorbs light at $540 \mathrm{~nm}$. In brief equal volumes of tissue sample and Griess reagent (5\% phosphoric acid containing 0.1\% NEDD, $1 \%$ sulfanilamide) was mixed and incubated in dark for $10 \mathrm{~min}$ at room temperature. After that the reaction mixture is measured at $540 \mathrm{~nm}$. The concentration of nitrite in the sample can be determined from a sodium nitrite $\left(\mathrm{NaNO}_{2}\right)$ standard curve [51].

\section{iNOS activity}

Forty microliters of Reaction Mixture (mixture contains $10 \mu \mathrm{L}$ Diluted NOS Cofactor $1+20 \mu \mathrm{L}$ NOS Cofactor 2 $(1 \mathrm{X})+5 \mu \mathrm{L}$ NOS Substrate $+5 \mu \mathrm{L}$ Nitrate Reductase) was taken in sample, standard and control tube and mix properly. Incubate it at $37^{\circ} \mathrm{C}$ for $1 \mathrm{~h}$. Ninety microliter of NOS Assay Buffer was added to sample, standard and control tube. Mixed well and then add $5 \mu \mathrm{L}$ of Enhancer to all. All the tubes were kept in room temperature for $10 \mathrm{~min}$ after proper mixing. Finally $50 \mu \mathrm{L}$ of Griess Reagent 1 and $50 \mu \mathrm{L}$ of Griess Reagent 2 were then added 
to all with proper mixing and incubated all the tubes at room temperature for $10 \mathrm{~min}$. Measured the OD at 540 $\mathrm{nm}$ and calculated the reading through the standard curve [51].

\section{Assessments of antioxidant enzymes}

Tissue antioxidant enzymes activities were measured according to standard protocol with slight modification. These are as follows:

\section{Determination of superoxide dismutase (SOD)}

The activity of superoxide dismutase (SOD) was measured according to a well-established reported method [52]. In brief, $2.5 \mathrm{~mL}$ reagent solution (xanthine $0.3 \mathrm{mM}$, EDTA $0.65 \mathrm{mM}, 140 \mu \mathrm{M} \mathrm{NBT}$ ), sodium carbonate $0.4 \mathrm{M}$, and bovine albumin $(35 \mathrm{mg} / 30 \mathrm{~mL})$ was added to $0.1 \mathrm{~mL}$ sample and $50 \mu \mathrm{L}$ xanthine oxidase $(10 \mu \mathrm{L}$ in $2 \mathrm{M}$ ammonium sulphate), incubated at $25^{\circ} \mathrm{C}$ for $20 \mathrm{~min}$ and mixed with, $0.1 \mathrm{~mL} 8 \mathrm{M}$ copper chloride. The developed color was measured at $560 \mathrm{~nm}$ and calculates the result with using co-factor.

\section{Determination catalase (CAT)}

Catalase activity was measured according to the method of Maehly (1955) [53, 54]. Briefly, on the aftermath of the addition of $5 \mu \mathrm{L}$ liver homogenate to $0.995 \mathrm{~mL} 30$ $\mathrm{mM} \mathrm{H}_{2} \mathrm{O}_{2}$ solution in potassium phosphate buffer ( $\mathrm{pH}$ 7.0), change in absorbance at $240 \mathrm{~nm}$ up to $1 \mathrm{~min}$ to determine catalase activity. The enzymatic activity was expressed as $\mathrm{U} / \mathrm{mg}$ protein.

\section{Determination of glutathione (GSH) and GPx content}

Reduced glutathione (GSH) was determined from liver homogenate spectrophotometrically according to Ellman's method [55]. GPx activity was assayed using a modified method of Hafeman. al [56].

\section{Determination TNF- $\alpha$ TGF $1 \beta$}

Levels of TNF and TGF in the liver were measured following the procedure provided with the purchased kit [57]. Protein levels were also measured according to the literature provided with the kit.

\section{TNF alpha}

All reagents, samples and standards were first prepared as instructed in the manual. Then $100 \mu \mathrm{l}$ of standard and tissue sample was added to the specific well. Incubated for $2 \mathrm{~h} 30 \mathrm{~min}$ at room temperature. After that $100 \mu \mathrm{l}$ freshly prepared biotin antibody was added to each well and incubated for $1 \mathrm{~h}$ at room temperature. Then $100 \mu \mathrm{l}$ freshly prepared streptavidin solution was added to each well and incubated for $45 \mathrm{~min}$ at room temperature. After that $100 \mu \mathrm{l}$ of TMB was added to each well and incubate for $30 \mathrm{~min}$ at room temperature. Finally $50 \mu \mathrm{l}$ of stop solution was added to each well and immediately read the reading at 450 nmusing a microplate reader.

\section{TGF-beta 1}

All reagents, samples and standards were freshly prepared according to manual. Ten microliters balance solution was added to each $100 \mu \mathrm{l}$ tissue sample and mixed with caution. One hundred microliters standard and sample was added to specific selected well. Then $50 \mu \mathrm{l}$ of 1x HRP-conjugate was added to each well except blank. Mixed gently and incubated for $60 \mathrm{~min}$ at $37^{\circ} \mathrm{C}$. Aspirated the liquid from each well and washed carefully. Approximately $350 \mu \mathrm{l}$ of $1 \mathrm{x}$ wash buffer was added through multi-channel pipette. All the tubes were kept for $15 \mathrm{~min}$ before completely aspirating. After the remaining wash, aspirating eliminated any closing Wash Buffer after which inverted the plate and tapped towards smooth absorbent paper. $50 \mu \mathrm{l}$ of substrate A and $50 \mu \mathrm{l}$ of substrate $B$ was added with gentle shaking. All the wells were kept in the dark for $15-20 \mathrm{~min}$ at $37^{\circ} \mathrm{C}$. Then $50 \mu \mathrm{l}$ of stop solution was added to each well. The blue color changed to yellow immediately. Blank contained only $100 \mu \mathrm{l}$ of PBS (0.02 mol/L pH 7.0-7.2). Optical density of each well immediately determined at $450 \mathrm{~nm}$ using a microplate reader.

\section{Hematoxylin and eosin staining}

Freshly liver sample was taken in a $4 \%$ formaldehyde saline solution and stored $72 \mathrm{~h}$. The tissue was embedded and prepares paraffin blocks. Five micron thin sections were deparaffinised and washed with water. After washing tissue sections were treated with Mayer's hematoxylin solution and kept for $5 \mathrm{~min}$. Observed the staining quality under microspore. If staining was perfect then counter stained with $1 \%$ eosin for $2 \mathrm{~min}$. The sections stained by the eosin and used dehydrated alcohol to remove any residual stain [58]. Mount the section with Canada balsam by using cover slip. Visualized the liver section under microscope and taken photographs through camera (Olympus BX51 fluorescence microscope) for further histological scoring analysis.

\section{Sirius red staining}

After the experimental period liver slices were fixed in $10 \%$ neutral buffered formalin for overnight and then transferred to $70 \%$ ethanol before imbedding in paraffin blocks. A paraffin-embedded liver tissue block was taken and cut into $5 \mathrm{~mm}$ thick sections. Paraffin-free sections were soaked for approximately $1 \mathrm{~h}$ in Pico-Sirius red solution (Abcam, Cambridge, MA) followed by a short rinse with acetic acid (0.05\%). Liver sections were dehydrated by washing with absolute alcohol [59]. Sections were observed with a light microscope (Olympus BX51 fluorescence microscope). 


\section{Statistical analysis}

Two-way analysis of variance (ANOVA) followed by Dunnett's multiple comparison tests were executed for comparison of different parameters between the groups using a computer program GraphPad Prism (version 5.00 for Windows), GraphPad Software, California, USA. $p$-values lower than $0.05(\mathrm{p}<0.05)$ were considered statistically significant.

\section{Results}

\section{Determination of phytochemical constituents}

Table 4 represents qualitative analysis of the plants secondary metabolites in water extract of multi herbal formulation (AKSS16-LIV01) revealed the presence of sterols in trace amount. After the closing wash, aspirating eliminated any last Wash Buffer after which inverted the plate and tapped towards smooth absorbent paper. Triterpenes weren't detected within the chloroform, ethanol, methanol and aqueous extract (Table 4). Saponins were detected in trace amount, flavonoids, alkaloids and glycosides were found to be moderately plethoric and therefore the presence of sterols was found to be abundant. This implies that a lot of secondary metabolites were found within the liquid extract that could be a sensible sign to determine the extract as a drug.

\section{Determination of physical morphology, body weight, liver} weight, liver index and food consumption

Figure 1 showed that chronic administration of ethanol retarded the overall growth and development (Fig. 1C) of the mice in compared with control untreated animal. Novel herbal formulation (AKSS16-LIV01) recovered the normal growth. Interestingly ethanol intoxication decreased gross body weight (Fig. 2B), food consumption (Fig. 2C) as well as daily water intake. Therapeutic treatment with AKSS16-LIV01 (150 \& $300 \mathrm{mg} / \mathrm{kg}$ ) prevent the toxic effects of ethanol and maintained the normal increasing body weight pattern. Moreover significantly increased liver weight and liver index (Fig. 2A) by ethanol intoxication was normalized through natural therapy (Fig. 2).

Table 4 Qualitative analysis of the phytochemical constituents of multi herbal formulation (AKSS16-LIV01)

\begin{tabular}{lllll}
\hline Phytochemicals & Ethanol & Methanol & Chloroform & Aqueous \\
\hline Sterols & $(+)$ & $(+)$ & $(+)$ & $(++)$ \\
Triterpenes & $(+)$ & $(++)$ & $(++)$ & $(+++)$ \\
Flavonoids & $(++)$ & $(++)$ & $(++)$ & $(+++)$ \\
Alkaloids & $(++)$ & $(+)$ & $(+)$ & $(++)$ \\
Saponins & $(+)$ & $(+)$ & $(+)$ & $(+)$ \\
Glycosides & $(+)$ & $(+)$ & $(+)$ & $(++)$ \\
Tannins & $(+)$ & $(+)$ & $(+)$ & $(++)$ \\
\hline
\end{tabular}

$(+)=$ traces,$(++)=$ moderate,$(+++)=$ abundant,$(-)=$ absence of constituents
Determination of serum AST, ALT, ALP, GGT and total protein level

Result presented in Fig. 3 indicated that levels of serum enzymes such as AST, ALT, ALP and GGT were significantly elevated $(P<0.001)$ in ethanol intoxicated mice compared with normal control mice. However in dose dependent study serum enzymes like AST, ALT, ALP and GGT were significantly reduced in multi herbal formulation (AKSS16-LIV01) at a dose of $75 \mathrm{mg} / \mathrm{kg}(P<$ $0.05), \quad 150 \mathrm{mg} / \mathrm{kg}(P<0.05)$ and $300 \mathrm{mg} / \mathrm{kg} \quad(P<0.001)$ respectively compared with ethanol treated mice. Moreover, Serum total protein level was significantly decreased $(P<0.001)$ in ethanol treated mice compared with normal control mice. Pre-treatment with multi herbal formulation (AKSS16-LIV01) significantly increased the serum total protein level at a dose of $75 \mathrm{mg} / \mathrm{kg}(P<0.05), 150 \mathrm{mg} / \mathrm{kg}$ $(P<0.05)$ and $300 \mathrm{mg} / \mathrm{kg}(P<0.001)$ respectively compared with ethanol treated mice. Multi herbal formulation (AKSS16-LIV01) showed 12\% better protective effect compared with standard drug silymarin. Administration of Multi herbal formulation (AKSS16-LIV01) at a dose of $300 \mathrm{mg} / \mathrm{kg}$ alone showed no such toxic effect in mice compared with control mice.

\section{Determination of serum BUN, total bilirubin, direct bilirubin, albumin level and albumin-globulin ratio}

Result presented in Table 5 indicated that levels of serum biochemical hepatotoxic marker such as blood urea nitrogen (BUN), total bilirubin and direct bilirubin were significantly elevated $(P<0.001)$ in ethanol intoxicated mice compared with normal control mice. However in dose dependent study serum enzymes like BUN, total bilirubin and direct bilirubin were significantly reduced in multi herbal formulation (AKSS16-LIV01) at a dose of $75 \mathrm{mg} / \mathrm{kg}(P<0.05), 150 \mathrm{mg} / \mathrm{kg}(P<0.05)$ and $300 \mathrm{mg} / \mathrm{kg}(P<0.001)$ respectively compared with ethanol treated mice. Moreover, Serum total albumin level and albumin-globulin ration was significantly decreased $(P<0.001)$ in ethanol treated mice compared with normal control mice. Pre-treatment with multi herbal formulation (AKSS16-LIV01) significantly increased the serum total albumin level and albumin-globulin ratio at a dose of $75 \mathrm{mg} / \mathrm{kg}(P<0.05), 150 \mathrm{mg} / \mathrm{kg}(P<0.05)$ and $300 \mathrm{mg} / \mathrm{kg}(P<0.001)$ respectively compared with ethanol treated mice. Multi herbal formulation (AKSS16LIV01) showed $10 \%$ better protective effect compared with standard drug silymarin. Administration of Multi herbal formulation (AKSS16-LIV01) at a dose of 300 $\mathrm{mg} / \mathrm{kg}$ alone showed no such toxic effect in mice compared with control mice.

\section{Determination of liver non enzymatic markers}

The total cholesterol, triglycerides, phospholipids, free fatty acids, LDL level of untreated ethanol control group 


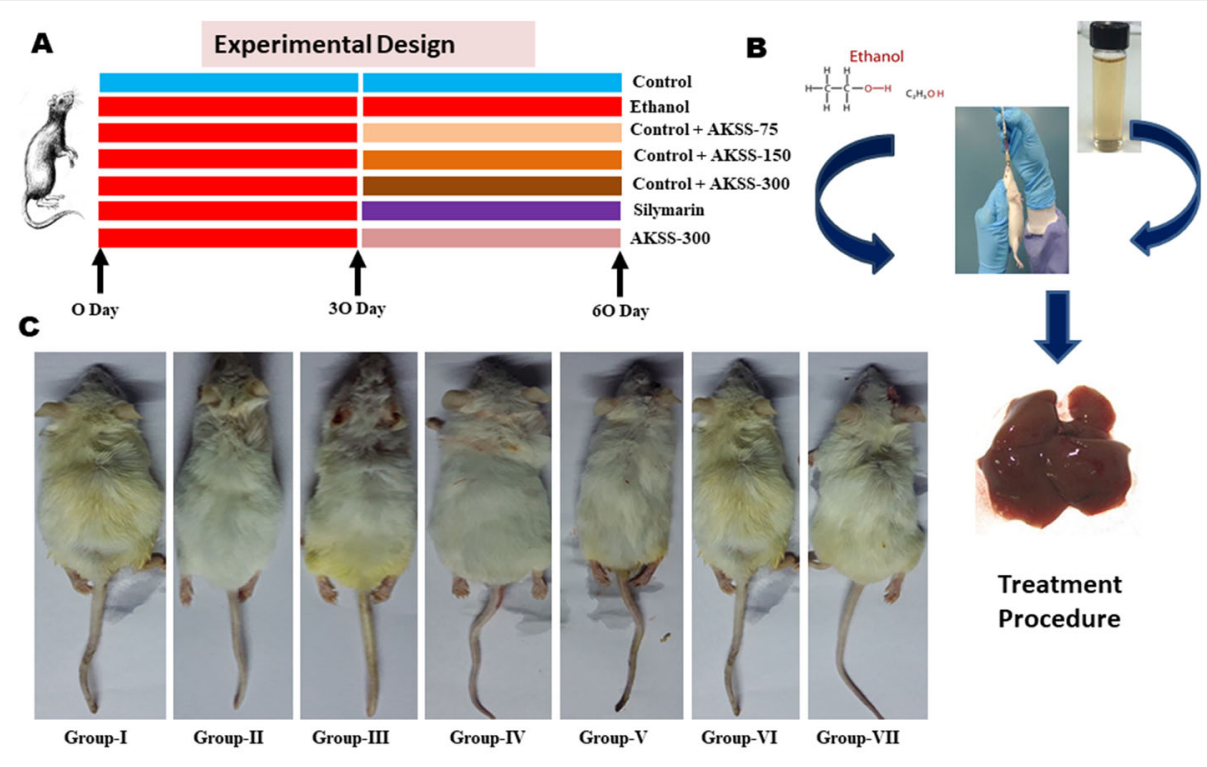

After Experimental Period

Fig. 1 In-vivo experiments upon experimental mice model. A Experimental design, B Experimental procedure, C External views of mice after experimental period

was significantly higher $(P<0.001)$ and HDL level significantly lower $(P<0.001)$ than the control groups presented in Table 6 . In contrast, the levels of cholesterol, triglycerides, phospholipids free fatty acids and LDL of the $75 \mathrm{mg} / \mathrm{kg}$ and $150 \mathrm{mg} / \mathrm{kg}$ body weight of multi herbal formulation (AKSS16-LIV01) with ethanol groups were significantly lower $(P<0.05)$ and HDL level significantly higher $(P<0.05)$ than the ethanol control group. Administration of multi herbal formulation (AKSS16-LIV01) at a dose of $300 \mathrm{mg} / \mathrm{kg}$ body, significantly normalise $(P<$

\section{Study of Morphological Parameters}

A

Table a: Summary of the body weight, liver weight and liver index of mice

\begin{tabular}{|l|l|l|l|l|l|l|l|}
\hline Parameters & Normal & ETHO & $\begin{array}{c}\text { ETHO+ AKSS- } \\
16-75\end{array}$ & $\begin{array}{c}\text { ETHO + AKSS- } \\
16-150\end{array}$ & $\begin{array}{c}\text { ETHO + AKSS- } \\
16-300\end{array}$ & Silymarin & AKSS-16-300 \\
\hline $\begin{array}{l}\text { Final Body } \\
\text { Weight (g) }\end{array}$ & $36.52 \pm 1.18$ & $27.94 \pm 1.22$ & $34.81 \pm 2.15$ & $35.01 \pm 1.34$ & $48.01 \pm 2.21$ & $38.26 \pm 2.17$ & $40.62 \pm 1.26$ \\
\hline Liver Weight (g) & $1.94 \pm 0.82$ & $3.50 \pm 0.28$ & $2.25 \pm 0.47$ & $1.98 \pm 0.18$ & $1.86 \pm 0.64$ & $2.03 \pm 0.64$ & $1.99 \pm 0.52$ \\
\hline Liver Index & $4.02 \pm 0.12$ & $7.72 \pm 0.15$ & $5.62 \pm 0.16$ & $5.65 \pm 0.17$ & $4.95 \pm 0.17$ & $5.22 \pm 0.18$ & $5.51 \pm 0.24$ \\
\hline
\end{tabular}

B

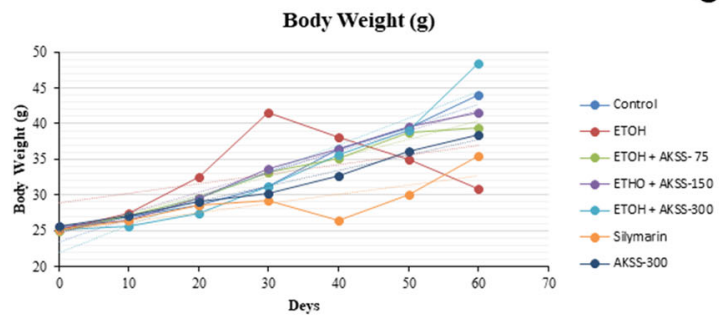

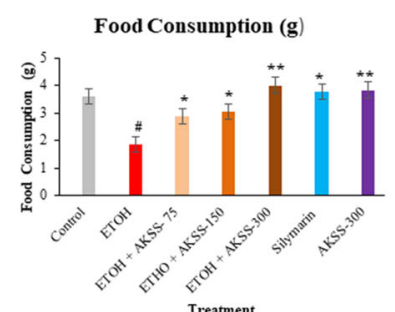

Fig. 2 Study of the morphological parameters. A Table showed summary of the body weight, liver weight and liver index in mice, B Day wise body weight, $\mathbf{C}$ Mean food consumption. The values are expressed as the mean \pm SEM. Significantly different from control ${ }^{\#} p<0.001$ and significantly different from ethanol $p<0.05,{ }^{* *} p<0.001$ using analysis of variance (ANOVA) followed by Dunnett's Multiple Comparison Test 


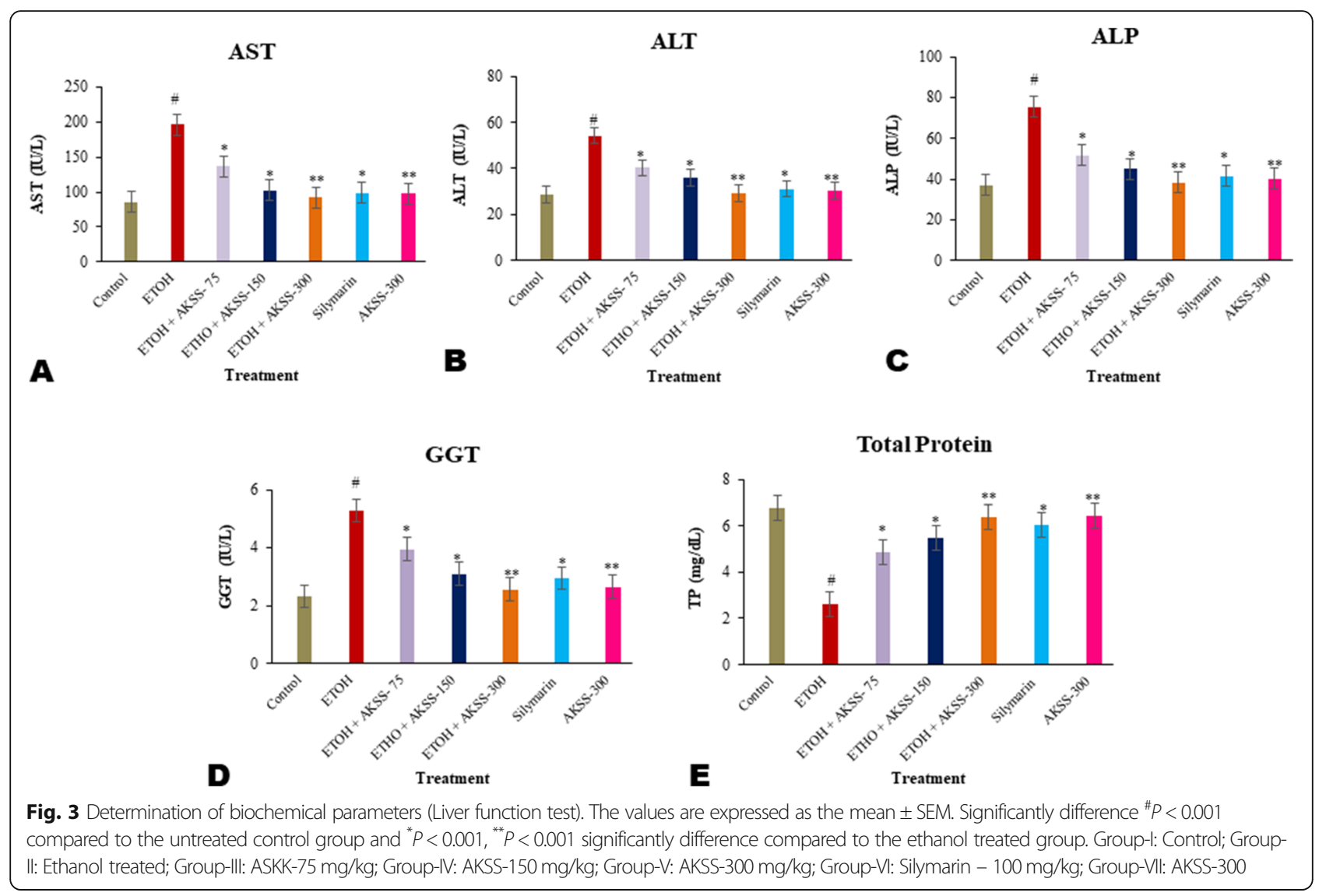

0.001) the deleterious effect (Table 6) caused by ethanol. Multi herbal formulation (AKSS16-LIV01) showed 15\% better protective effect compared with standard drug silymarin. Administration of Multi herbal formulation (AKSS16-LIV01) at a dose of $300 \mathrm{mg} / \mathrm{kg}$ alone showed no such toxic effect in mice compared with control mice.

\section{Determination of Haematological parameters}

The hematopoietic system is one of the target organs of ethanol toxicity. The results concerning hematologic parameters depicted the Table 7 showed a significant $(p<$ 0.001 ) decline in total erythrocyte count, total leukocyte count, hemoglobin concentration, Mean corpuscular haemoglobin concentration, neutrophil content and monocyte content in the ethanol treated animals. On the other hand, reticulocyte content content insignificantly increased in ethanol treated group, when compared with control animals. Gradually all the above mentioned parameters recover in the dose dependent AKSS16-LIV01 treated groups as compared with standard drug silymarin.

\section{Determination of liver hydroxyproline level}

Table 8 showed the hydroxyproline level of control and experimental group. In our study, long term ethanol intoxication produced deleterious effects which was clearly indicated when we found that hydroxyprolein level significantly elevated $(P<0.001)$ in experimental mice with compared with normal untreated group. Pre-treatment

Table 5 Effect of AKSS16-LIV01 on liver function test parameters across the groups in chronic ethanol-induced hepatic damage in mice

\begin{tabular}{|c|c|c|c|c|c|c|c|}
\hline Parameters & Normal & Ethanol & $\begin{array}{l}\text { Ethanol + AKSS16- } \\
\text { LIV01 (75) }\end{array}$ & $\begin{array}{l}\text { Ethanol+AKSS16- } \\
\text { LIV01 (150) }\end{array}$ & $\begin{array}{l}\text { Ethanol+AKSS16- } \\
\text { LIV01 (300) }\end{array}$ & $\begin{array}{l}\text { Ethanol } \\
+ \text { Silymarin(100) }\end{array}$ & $\begin{array}{l}\text { AKSS16- } \\
\text { LIV01 (300) }\end{array}$ \\
\hline$\overline{B U N}(\mathrm{mg} / \mathrm{dl})$ & $0.41 \pm 0.02$ & $0.72 \pm 0.04^{\#}$ & $0.58 \pm 0.04^{*}$ & $0.67 \pm 0.02^{*}$ & $0.46 \pm 0.02^{* *}$ & $0.54 \pm 0.03^{*}$ & $0.46 \pm 0.03^{*}$ \\
\hline Total Bilirubin (mg/dl) & $0.12 \pm 0.2$ & $0.62 \pm 0.11^{\#}$ & $0.22 \pm 0.09^{*}$ & $0.34 \pm 0.08^{*}$ & $0.16 \pm 0.09^{* *}$ & $0.24 \pm 0.08^{*}$ & $0.19 \pm 0.11^{*}$ \\
\hline Direct Bilirubin (mg/dl) & $0.06 \pm 0.001$ & $0.33 \pm 0.07^{\#}$ & $0.19 \pm 0.002^{*}$ & $0.09 \pm 0.003^{*}$ & $0.09 \pm 0.002^{* *}$ & $0.11 \pm 0.005^{*}$ & $0.07 \pm 0.002^{*}$ \\
\hline Alb (gr/dL) & $3.48 \pm 0.186$ & $1.97 \pm 0.036^{\#}$ & $2.85 \pm 0.12^{*}$ & $3.70 \pm 0.11^{*}$ & $4.02 \pm 0.14^{* *}$ & $3.32 \pm 0.15^{*}$ & $3.16 \pm 0.13^{*}$ \\
\hline Alb/globulin & $1.18 \pm 0.141$ & $0.54 \pm 0.013^{\#}$ & $0.81 \pm 0.091^{*}$ & $0.91 \pm 0.096^{*}$ & $1.21 \pm 0.95^{* *}$ & $1.04 \pm 0.091^{*}$ & $0.98 \pm 0.135^{*}$ \\
\hline
\end{tabular}

The values are expressed as the mean \pm SEM. Significantly different from control ${ }^{\#} p<0.001$ and significantly different from ethanol $p<0.05,{ }^{* *} p<0.001$ using analysis of variance (ANOVA) followed by Dunnett's Multiple Comparison Test 
Table 6 Effect of AKSS16-LIV01 on concentrations of nonenzymatic biochemical parameters in chronic ethanol-induced hepatic damage in mice

\begin{tabular}{|c|c|c|c|c|c|c|c|}
\hline Parameters & Normal & Ethanol & $\begin{array}{l}\text { Ethanol + AKSS16- } \\
\text { LIV01 (75) }\end{array}$ & $\begin{array}{l}\text { Ethanol+AKSS16- } \\
\text { LIV01 (150) }\end{array}$ & $\begin{array}{l}\text { Ethanol+AKSS16- } \\
\text { LIV01 (300) }\end{array}$ & $\begin{array}{l}\text { Ethanol } \\
+ \text { Silymarin(100) }\end{array}$ & $\begin{array}{l}\text { AKSS16- } \\
\text { LIV01 (300) }\end{array}$ \\
\hline Cholesterol (mg/dL) & $80.17 \pm 5402$ & $138.99 \pm 6.23^{\#}$ & $91.25 \pm 2.99^{*}$ & $91.47 \pm 2.37^{*}$ & $79.36 \pm 4.35^{* *}$ & $856.11 \pm 2.98^{*}$ & $88.05 \pm 3.16^{*}$ \\
\hline Triglyceride (mg/dL) & $42.55 \pm 3.56$ & $75.66 \pm 4.28^{\#}$ & $68.61 \pm 3.24^{*}$ & $47.98 \pm 1.97^{*}$ & $37.25 \pm 1.87^{* *}$ & $44.75 \pm 3.25^{*}$ & $51.23 \pm 3.01^{*}$ \\
\hline Phospgolipids (mg/dL) & $78.48 \pm 5.29$ & $141.51 \pm 5.14^{\#}$ & $91.72 \pm 2.66^{*}$ & $98.51 \pm 3.28^{*}$ & $82.69 \pm 4.87^{* *}$ & $88.03 \pm 2.84^{*}$ & $92.37 \pm 2.66^{*}$ \\
\hline $\begin{array}{l}\text { Free fatty acids } \\
(\mathrm{mg} / \mathrm{dL})\end{array}$ & $14.07 \pm 0.79$ & $34.87 \pm 1.87^{\#}$ & $24.33 \pm 1.91^{*}$ & $21.22 \pm 1.69^{*}$ & $14.09 \pm 1.22^{* *}$ & $19.27 \pm 2.01^{*}$ & $20.14 \pm 1.96^{*}$ \\
\hline $\begin{array}{l}\text { LDL-cholesterol } \\
(\mathrm{mg} / \mathrm{dL})\end{array}$ & $38.11 \pm 1.91$ & $76.94 \pm 1.77^{\#}$ & $44.61 \pm 2.88^{*}$ & $45.78 \pm 1.65^{*}$ & $36.85 \pm 1.25^{* *}$ & $42.52 \pm 2.28^{*}$ & $43.61 \pm 1.88^{*}$ \\
\hline $\begin{array}{l}\text { HDL-cholesterol } \\
(\mathrm{mg} / \mathrm{dL})\end{array}$ & $19.52 \pm 0.88$ & $9.21 \pm 0.68^{\#}$ & $16.25 \pm 0.62^{*}$ & $16.24 \pm 0.41^{*}$ & $10.28 \pm 0.28^{* *}$ & $21.57 \pm 0.99^{*}$ & $15.28 \pm 0.55^{*}$ \\
\hline
\end{tabular}

The values are expressed as the mean \pm SEM. Significantly different from control ${ }^{*} p<0.001$ and significantly different from ethanol $p<0.05,{ }^{* *} p<0.001$ using analysis of variance (ANOVA) followed by Dunnett's Multiple Comparison Test

with multi herbal formulation (AKSS16-LIV01) significantly reduce at a dose of $75 \mathrm{mg} / \mathrm{kg}(P<0.05), 150 \mathrm{mg} /$ $\mathrm{kg}(P<0.05)$ and $300 \mathrm{mg} / \mathrm{kg}(P<0.001)$ respectively compared with ethanol treated mice (Group-II). Multi herbal formulation (AKSS16-LIV01) showed 15\% better protective effect compared with standard drug silymarin (Group-VI). Administration of Multi herbal formulation (AKSS16-LIV01) at a dose of $300 \mathrm{mg} / \mathrm{kg}$ alone (GroupVII) showed no such toxic effect in mice compared with control mice.

\section{Determination of NO and iNOS}

In this study result showed that in Table 8 ethanol intoxication significantly elevated $(P<0.001) \mathrm{NO}$ content and iNOS level in mice as compared with normal untreated group. Pre-treatment with multi herbal formulation (AKSS16-LIV01) significantly reduce at a dose of $75 \mathrm{mg} / \mathrm{kg}(P<0.05), 150 \mathrm{mg} / \mathrm{kg}(P<0.05)$ and $300 \mathrm{mg} / \mathrm{kg}$ $(P<0.001)$ respectively compared with ethanol treated mice (Group-II). Multi herbal formulation (AKSS16LIV01) showed $12 \%$ better protective effect compared with standard drug silymarin (Group-VI). Administration of Multi herbal formulation (AKSS16-LIV01) at a dose of $300 \mathrm{mg} / \mathrm{kg}$ alone (Group-VII) showed no such toxic effect in mice compared with control mice.

\section{Determination of MDA and ROS level}

Result presented in Table 8 and Fig. 4 indicated that level of lipid peroxidation (MDA level) and the tissue ROS levels. Both lipid peroxidation and ROS content

Table 7 Effect of AKSS16-LIV01 on haematological parameters in chronic ethanol-induced hepatic damage in mice

\begin{tabular}{|c|c|c|c|c|c|c|c|}
\hline Parameters & Normal & Ethanol & $\begin{array}{l}\text { Ethanol + AKSS16- } \\
\text { LIV01 (75) }\end{array}$ & $\begin{array}{l}\text { Ethanol+AKSS16- } \\
\text { LIV01 (150) }\end{array}$ & $\begin{array}{l}\text { Ethanol+AKSS16- } \\
\text { LIV01 (300) }\end{array}$ & $\begin{array}{l}\text { Ethanol } \\
\text { +Silymarin(100) }\end{array}$ & $\begin{array}{l}\text { AKSS16-LIV01 } \\
(300)\end{array}$ \\
\hline $\mathrm{Hb}(\mathrm{g} \%)$ & $12.1 \pm 1.05$ & $9.03 \pm 0.89^{\#}$ & $12.0 \pm 1.02^{*}$ & $11.05 \pm 0.99^{*}$ & $12.51 \pm 0.95^{* *}$ & $10.96 \pm 0.74$ & $11.21 \pm 0.82$ \\
\hline $\begin{array}{l}\mathrm{RBC}\left(\times 10^{6}\right. \\
\left.\mathrm{cm}^{2}\right)\end{array}$ & $10.8 \pm 0.82$ & $8.1 \pm 0.71^{\#}$ & $10.5 \pm 0.77^{*}$ & $9.44 \pm 0.71$ & $10.02 \pm 0.85^{*}$ & $9.85 \pm 0.79$ & $9.62 \pm 0.84$ \\
\hline RT (\%) & $2.7 \pm 0.12$ & $4.9 \pm 0.26^{\#}$ & $2.6 \pm 0.14^{*}$ & $3.1 \pm 0.14$ & $2.8 \pm 0.15^{*}$ & $3.0 \pm 0.12^{*}$ & $3.6 \pm 0.16$ \\
\hline HCT (\%) & $34.6 \pm 0.48$ & $39.4 \pm 0.55^{\#}$ & $34.1 \pm 0.44^{*}$ & $35.8 \pm 0.51$ & $34.9 \pm 0.56^{*}$ & $34.4 \pm 0.51^{*}$ & $35.1 \pm 0.77$ \\
\hline$M C V\left(\mu m^{3}\right)$ & $37.8 \pm 0.32$ & $31.0 \pm 0.68$ & $36.7 \pm 0.29^{*}$ & $36.5 \pm 0.44$ & $35.9 \pm 0.79$ & $36.2 \pm 0.43^{*}$ & $35.5 \pm 0.36$ \\
\hline $\mathrm{MCH}(\mathrm{pg})$ & $21.2 \pm 0.15$ & $22.2 \pm 0.14^{\#}$ & $22.8 \pm 0.23^{*}$ & $21.1 \pm 0.12^{*}$ & $21.4 \pm 0.11^{*}$ & $21.2 \pm 0.14$ & $21.1 \pm 0.12$ \\
\hline MCHC (\%) & $41.2 \pm 1.06$ & $32.4 \pm 0.95^{\#}$ & $40.2 \pm 1.07$ & $37.1 \pm 0.92$ & $39.6 \pm 0.87^{*}$ & $38.6 \pm 0.99$ & $36.2 \pm 0.91$ \\
\hline Platelets & $6.5 \pm 0.02$ & $5.5 \pm 0.03$ & $6.5 \pm 0.04$ & $5.8 \pm 0.05$ & $6.1 \pm 0.07$ & $5.5 \pm 0.05$ & $5.4 \pm 0.06$ \\
\hline $\begin{array}{l}\text { WBC }\left(\times 10^{5}\right. \\
\left.\mathrm{cm}^{2)}\right)\end{array}$ & $9.2 \pm 0.09$ & $12.4 \pm 0.11^{\#}$ & $9.1 \pm 0.08$ & $10.8 \pm 0.12$ & $9.2 \pm 0.11^{* *}$ & $10.1 \pm 0.13$ & $10.7 \pm 0.11$ \\
\hline Lymphocyte & $74 \pm 2.98$ & $79 \pm 3.04^{\#}$ & $72 \pm 2.54^{*}$ & $73 \pm 3.06^{*}$ & $74 \pm 2.58^{*}$ & $72 \pm 3.08^{*}$ & $71 \pm 3.11$ \\
\hline Neutrophil & $26 \pm 1.12$ & $15 \pm 0.49^{\#}$ & $24 \pm 1.09^{*}$ & $20 \pm 0.56^{*}$ & $25 \pm 0.69^{* *}$ & $24 \pm 0.51^{*}$ & $21.52 \pm 2.09$ \\
\hline
\end{tabular}

Data are expressed as mean \pm standard deviation $(N=6)$. $H b$ Haemoglobin, RBC Read Blood corpuscle, RT Reticulocyte, $H C T$ Haematocrit, $M C V$ Mean corpuscular volume, $M C H$ Mean corpuscular haemoglobin, $M C H C$ Mean corpuscular haemoglobin concentration, WBC White Blood corpuscle

The values are expressed as the mean \pm SEM. Significantly different from control ${ }^{\#} p<0.001$ and significantly different from ethanol $p<0.05,{ }^{* *} p<0.001$ using analysis of variance (ANOVA) followed by Dunnett's Multiple Comparison Test 
Table 8 Effect of AKSS16-LIV01 onliver Lipid peroxidation, NO, iNOS levels and Hydroxyproline concentration in chronic ethanolinduced hepatic damage in mice

\begin{tabular}{|c|c|c|c|c|c|c|c|}
\hline Parameters & Normal & Ethanol & $\begin{array}{l}\text { Ethanol + } \\
\text { AKSS16-LIV01 } \\
\text { (75) }\end{array}$ & $\begin{array}{l}\text { Ethanol+AKSS16- } \\
\text { LIV01 (150) }\end{array}$ & $\begin{array}{l}\text { Ethanol+AKSS16- } \\
\text { LIV01 (300) }\end{array}$ & $\begin{array}{l}\text { Ethanol } \\
+ \text { Silymarin(100) }\end{array}$ & $\begin{array}{l}\text { AKSS16- } \\
\text { LIV01 (300) }\end{array}$ \\
\hline $\begin{array}{l}\text { Lipid Peroxidation } \\
\text { (nm/100 g tissue) }\end{array}$ & $68.16 \pm 3.52$ & $182.16 \pm 3.09$ & $92.35 \pm 2.14^{*}$ & $47^{*}$ & $62.58 \pm 2.52^{* *}$ & $82.57 \pm 1.67^{*}$ & $66.57 \pm 0.99^{*}$ \\
\hline $\mathrm{NO}(\mu \mathrm{mol} / \mathrm{mg}$ protein) & $0.64 \pm 0.004$ & $2.29 \pm 0.002^{\#}$ & $102.77 \pm 0.005^{*}$ & $0.84 \pm 0.004^{*}$ & $0.69 \pm 0.006^{* *}$ & $0.88 \pm 0.007^{*}$ & $0.65 \pm 0.002^{*}$ \\
\hline iNOS (U/mg protein) & $0.32 \pm 0.003$ & $1.11 \pm 0.002^{\#}$ & $0.62 \pm 0.005^{*}$ & $0.46 \pm 0.006^{*}$ & $0.38 \pm 0.003^{* *}$ & $0.45 \pm 0.005^{*}$ & $0.39 \pm 0.003^{*}$ \\
\hline Hydroxyproline (mq/g) & $0.42 \pm 0.004$ & $0.99 \pm 0.004^{\#}$ & $0.76 \pm 0.006^{*}$ & $0.55 \pm 0.003^{*}$ & $0.47 \pm 0.002^{* *}$ & $0.56 \pm 0.004^{*}$ & $0.44 \pm 0.005^{*}$ \\
\hline
\end{tabular}

The values are expressed as the mean \pm SEM. Significantly different from control ${ }^{\#} p<0.001$ and significantly different from ethanol ${ }^{*} p<0.05,{ }^{* *} p<0.001$ using analysis of variance (ANOVA) followed by Dunnett's Multiple Comparison Test

were significantly elevated $(P<0.001)$ in ethanol intoxicated mice compared with normal control mice. However in dose dependent study MDA and ROS content were significantly reduced in multi herbal formulation (AKSS16-LIV01) at a dose of $75 \mathrm{mg} / \mathrm{kg}(P<0.05), 150$ $\mathrm{mg} / \mathrm{kg}(P<0.05)$ and $300 \mathrm{mg} / \mathrm{kg}(P<0.001)$ respectively compared with ethanol treated mice. Multi herbal formulation (AKSS16-LIV01) showed 12-13\% better protective effect compared with standard drug silymarin. Administration of Multi herbal formulation (AKSS16LIV01) at a dose of $300 \mathrm{mg} / \mathrm{kg}$ alone showed no such toxic effect in mice compared with control mice.
Determination of TNF- $\alpha$ and TGF $1 \beta$

Inflammation is commonly associated with liver dysfunction and fibrosis during chronic liver injury. The values of proinflammatory cytokines like TNF- $\alpha$ were determined from the hepatic tissue sample. Table 9 shows significant increase $(p<0.001)$ of TNF- $\alpha$ in ethanol treated mice when compared to control untreated animals. The elevated level of TNF- $\alpha$ was significantly inhibited $(p<0.05, p<0.001)$ by the application of multi herbal formulation (AKSS16-LIV01) in dose dependent manner 150 and $300 \mathrm{mg} / \mathrm{kg}$ ). This observation was comparable to that of the standard drug silymarin.

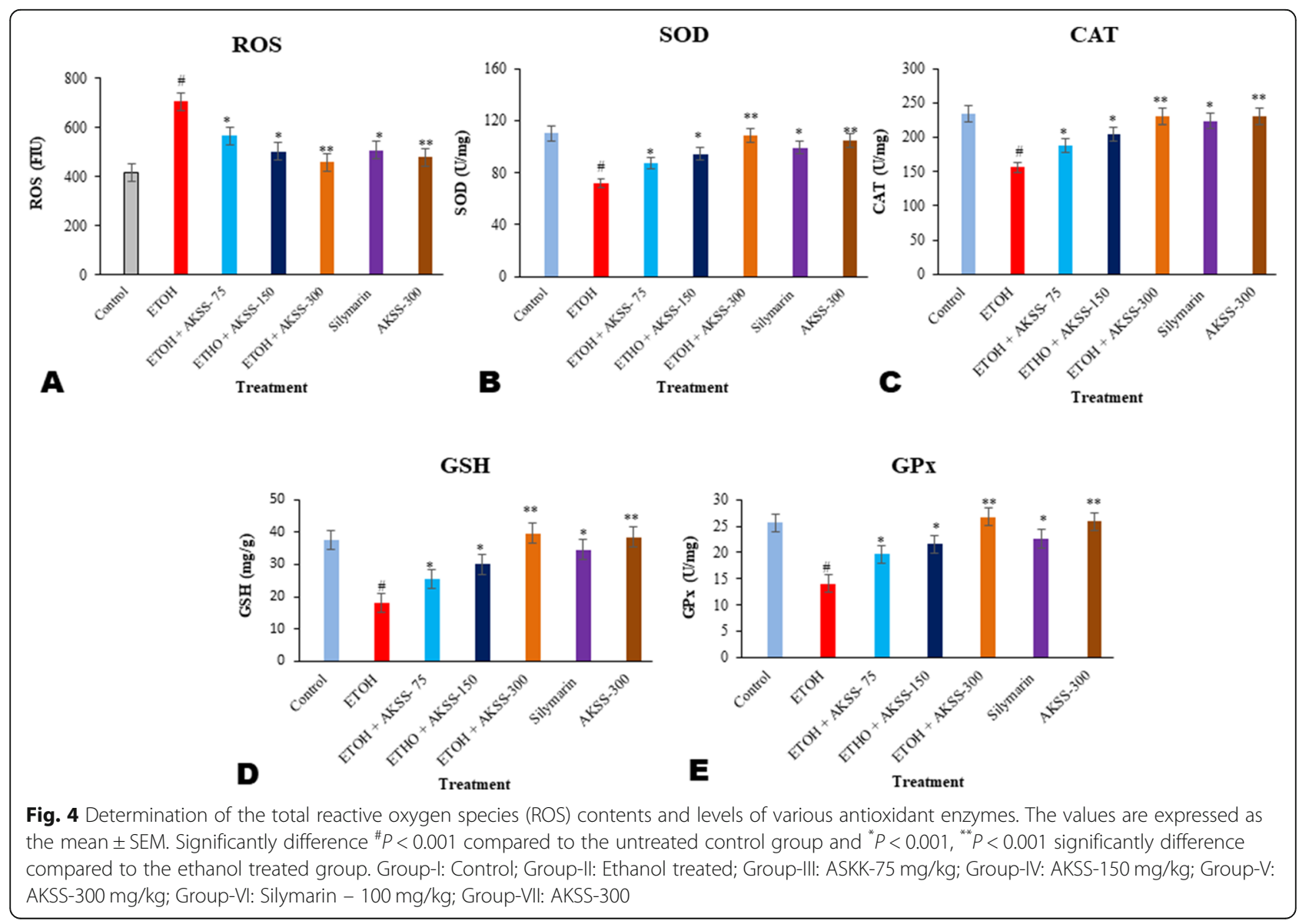


Therapeutic application of AKSS16-LIV01at a dose of $300 \mathrm{mg} / \mathrm{kg}$ showed optimum protective potential against ethanol induce liver intoxication. TGF $1 \beta$ is the major profibrogenic cytokine. As shown in Table 9 significantly increased level of TGF $1 \beta$ was observed in ethanol treated mice when compared to control untreated animals. On the other hand, treatment with AKSS16-LIV01 both $150 \mathrm{mg} / \mathrm{kg}$ and $300 \mathrm{mg} / \mathrm{kg}$ significantly decreased $(p<0.05, p<0.001)$ the level of TGF $1 \beta$ when compared with ethanol treated animals. This observation was comparable to that of the standard drug silymarin. Therapeutic application of AKSS16-LIV01at a dose of $300 \mathrm{mg} /$ $\mathrm{kg}$ alone showed optimum protective potential against ethanol induce liver dysfunction.

\section{Determination of SOD, CAT, GSH and GPx level}

Result depicted in Fig. 4 indicated that levels of different antioxidant enzymes such as SOD, CAT, GSH and GPx were significantly reduce $(P<0.001)$ in ethanol intoxicated mice compared with normal control mice. However in dose dependent study the above antioxidant enzymes i.e. SOD, CAT, GSH and GPx were significantly reduced in multi herbal formulation (AKSS16-LIV01) at a dose of $75 \mathrm{mg} / \mathrm{kg}$ $(P<0.05), 150 \mathrm{mg} / \mathrm{kg}(P<0.05)$ and $300 \mathrm{mg} / \mathrm{kg}(P<0.001)$ respectively compared with ethanol treated mice. Multi herbal formulation (AKSS16-LIV01) showed 12-13\% better protective effect compared with standard drug silymarin. Administration of Multi herbal formulation (AKSS16LIV01) at a dose of $300 \mathrm{mg} / \mathrm{kg}$ alone showed no such toxic effect in mice compared with control mice.

\section{Histopathological examination}

Histologic examination Fig. 5 shows normal morphological architecture under light microscope of $H \& E$ in the control group. In the ethanol treated intoxicated groups $(50: 50 \mathrm{v} / \mathrm{v})$ necrosis, hyperemia, vacuolar degeneration and infiltration of the inflammatory cells were observed which indicated hepatocellular damage (Fig. 5). In this regards, administration of multi herbal formulation (AKSS16-LIV01) at a dose of $75 \mathrm{mg} / \mathrm{kg}$ showed less damages compared with ethanol intoxicated mice (Fig. 6). Mild necrosis vacuolar degeneration and infiltration of the inflammatory cells were observed in the group 4 $(150 \mathrm{mg} / \mathrm{kg})$. In the group $5(300 \mathrm{mg} / \mathrm{kg})$ only mild vacuolar degeneration and infiltration of the inflammatory cells were seen which may indicate that the treatment of multi herbal formulation (AKSS16-LIV01) was very effective (Fig. 5). Histopathologic parameters of the liver tissues were graded in Fig. 5e. Masson trichrom and serius red staining photographs showed that liver's normal architectures completely massed by chronic administration of ethanol and deleterious effect was completely restored by AKSS16-LIV01 $(300 \mathrm{mg} / \mathrm{kg})$ which fully supported the above results.

\section{Discussion}

People all over the globes widely consume alcoholic drinks and consequently suffer from various diseases such as liver cirrhosis, liver fibrosis, fatty liver and, hepatic cell carcinoma (liver cancer). The condition produces hepatic dysfunctions that alter the body's normal homeostasis [60-62]. From ancient times, Indian medicinal herbs and spices are very useful for liver complications by boosting the antioxidant system and make a balance between antioxidants and prooxidants. These herbs and spices are enriched with polyphenols, flavonoids, tannins, proteins, amino acids, saponin, etc. which play a key role in liver protection against various toxicants. It also increases the body's antioxidant ability which further increases the immune power for fighting against disease. In the present study, we developed a multi herbal formulation (MHF) composed of six Indian medicinal herbs and three Indian medicinal spices (AKSS16-LIV01) have cumulative actions in comparison with the single herbal extract. We try to establish its antioxidant and immune-suppressive effect against ethanol intoxication and find out a new safe and symptomatic medication in liver dysfunction.

The preclinical and clinical studies have already established that ethanol is a potent hepatotoxicant which produces severe liver complications [63]. Liver damage by ethanol is closely associated with the generation of reactive oxygen species (ROS) such as peroxide, singlet oxygen, superoxide anion, hydroxyl ions which elevates MDA (malondialdehyde), NO (nitric oxide) and iNOS (nitric oxide synthase), suppress the cellular integrity. Ethanol intoxication showed the function of the various antioxidant enzymes gets severely reduced causing cell

Table 9 Effect of AKSS16-LIV01 on TNF $a$ and TGF $1 \beta$ levels in liver tissue in chronic ethanol-induced hepatic damage in mice

\begin{tabular}{|c|c|c|c|c|c|c|c|}
\hline Parameters & Normal & Ethanol & $\begin{array}{l}\text { Ethanol + } \\
\text { AKSS16-LIV01 } \\
(75)\end{array}$ & $\begin{array}{l}\text { Ethanol+AKSS16- } \\
\text { LIV01 (150) }\end{array}$ & $\begin{array}{l}\text { Ethanol+AKSS16- } \\
\text { LIV01 (300) }\end{array}$ & $\begin{array}{l}\text { Ethanol + } \\
\text { Silymarin (100) }\end{array}$ & $\begin{array}{l}\text { AKSS16-LIV01 } \\
(300)\end{array}$ \\
\hline $\begin{array}{l}\text { TNF-a (pg/ } \\
\text { mg protein) }\end{array}$ & $1411.91 \pm 206.53$ & $2344.77 \pm 371.98^{\#}$ & $1636.77 \pm 220.97^{*}$ & $1572.25 \pm 236.93^{*}$ & $1437.11 \pm 285.83^{* *}$ & $1478.26 \pm 288.17^{*}$ & $1422.87 \pm 198.54^{*}$ \\
\hline $\begin{array}{l}\text { TGF-1 } \beta \text { (pg/ } \\
\text { mg protein) }\end{array}$ & $485.90 \pm 91.34$ & $1237.05 \pm 125.78^{\#}$ & $702.38 \pm 98.77^{*}$ & $598.11 \pm 212.45^{*}$ & $474.03 \pm 102.76^{* *}$ & $552.03 \pm 203.84^{*}$ & $492.11 \pm 88.16^{*}$ \\
\hline
\end{tabular}

The values are expressed as the mean \pm SEM. Significantly different from control ${ }^{\#} p<0.001$ and significantly different from ethanol $p<0.05$, ${ }^{* *} p<0.001$ using analysis of variance (ANOVA) followed by Dunnett's Multiple Comparison Test 


\section{Study of Histopathology}

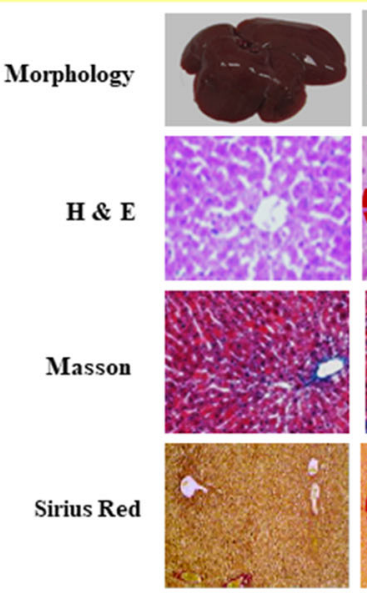

Control
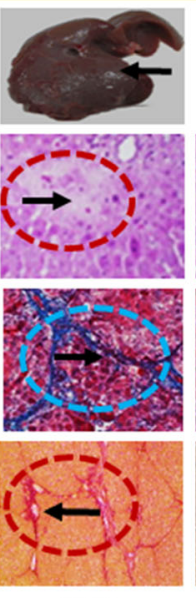

ETHO
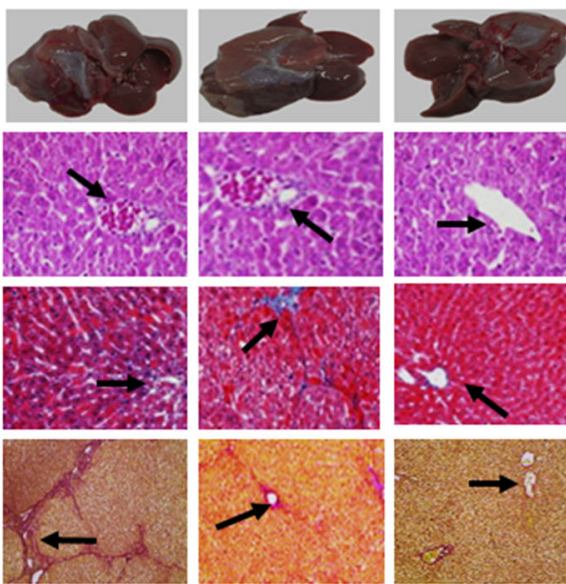

ETHO + AKSS-75
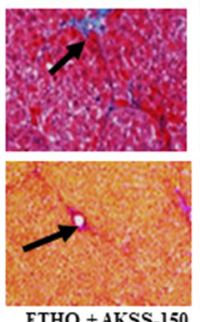

ETHO + AKSS-150
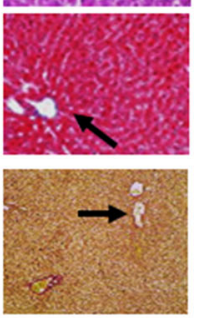

ETHO + AKSS-300
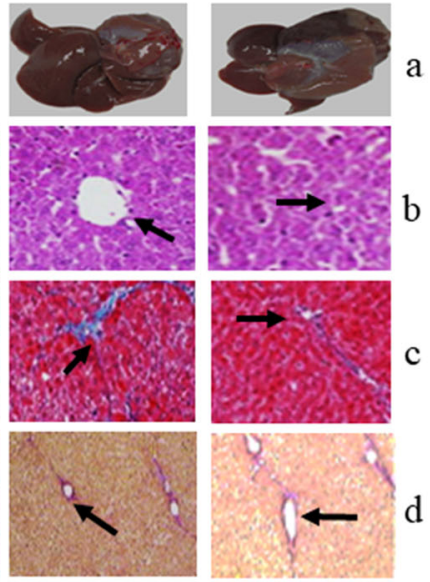

Silymarin

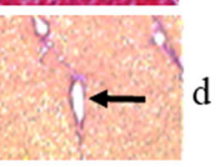

AKSS-300

e Table: Lesion Scores of Different Liver Alterations among all Experimental Groups

\begin{tabular}{|l|c|c|c|c|c|c|}
\hline Histopathological lesions & Normal & ETHO & $\begin{array}{c}\text { ETHO + AKSS- } \\
75\end{array}$ & $\begin{array}{c}\text { ETHO + AKSS- } \\
150\end{array}$ & $\begin{array}{c}\text { ETHO + AKSS- } \\
300\end{array}$ & $\begin{array}{c}\text { Silymarin } \\
\text { AKSS-300 }\end{array}$ \\
\hline $\begin{array}{l}\text { Fibroblast proliferation in } \\
\text { the capsule }\end{array}$ & - & ++ & + & - & - & - \\
\hline $\begin{array}{l}\text { Fibroblast proliferation in } \\
\text { the portal triad }\end{array}$ & - & ++ & ++ & + & - & - \\
\hline Focal hepatic necrosis & - & + & + & + & - & - \\
\hline Steatosis of hepatocytes & - & ++ & + & - & - \\
\hline $\begin{array}{l}\text { Cytoplasmic vacuolization } \\
\text { of hepatocytes }\end{array}$ & - & + & - & - & - \\
\hline Kupffer cell activation & - & ++ & - & - & - \\
\hline
\end{tabular}

Fig. 5 Representative photomicrographs of livers in different experimental groups. a liver morphology $\mathbf{b} \mathrm{H}$ \& $\mathrm{E}$ stained liver sections $\mathbf{c}$ Masson trichrom stained liver sections $\mathbf{d}$ Sirius red stained liver sections. e Table showed histological scoring of the liver section in different groups

apoptosis [64, 65]. Increased and decreased enzymatic and non-enzymatic markers of serum were also associated with this condition. Alcoholic liver disease (ALD) was normally found in liver histology, which disrupts the normal liver architecture and reduces regular functions. Our developed formulation AKSS16-LIV01 was enriched with antioxidants that could revert and lower the free radicals level. It had shown that the beneficial effects of this phytomedicine in preventing the ethanol-induced hepatotoxicity caused by free radicals.

In the present study, we evaluated the ameliorative effects of AKSS16-LIV01 against ethanol-induced hepatotoxicity in the animal model. Dose-dependent administration of ethanol increased the gross liver weight and liver-body weight ratio and decreased the cumulative body weight, which caused the changes in the behavior of mice. Administration of AKSS16-LIV01 with three specific doses gradually normalized the changes. Ethanol intoxication elevated the concentrations of key cellular enzymes like AST, ALT, ALP, and GGT present in the liver cells that leak into the serum during liver damage [66-70]. This happens because of a higher concentration of alcohol dehydrogenase in the liver, which catalyzes alcohol to its corresponding aldehyde [71]. Therefore, administration of AKSS16-LIV01 at a dose of $150 \mathrm{mg}$ and $300 \mathrm{mg}$ body weight could help to normalize the AST, ALT, ALP, and GGT enzyme levels. So, the developed multi herbal formulation AKSS16-LIV01 could reduce the level of these enzyme markers.

These results are also consistent with the protective effects of the developed formulation correlating with its antioxidant ability against alcohol-induced hepatocyte cells of the liver [72-74]. Our results also showed that administration of ethanol increased the serum essential enzymes blood urea nitrogen (BUN), total and direct bilirubin which was reverted with the treatment of AKSS16-LIV01. On the other hand, it was found that ethanol toxicity reduces the body's different protein concentration and breaks the normal homeostasis. Our results showed that reduced total protein, albumin, and albumin globulin ratio were normalized by AKSS16LIV01.

Ethanol administration increased serum total cholesterol (TC), total triglyceride (TC), phospholipids, LDL, 


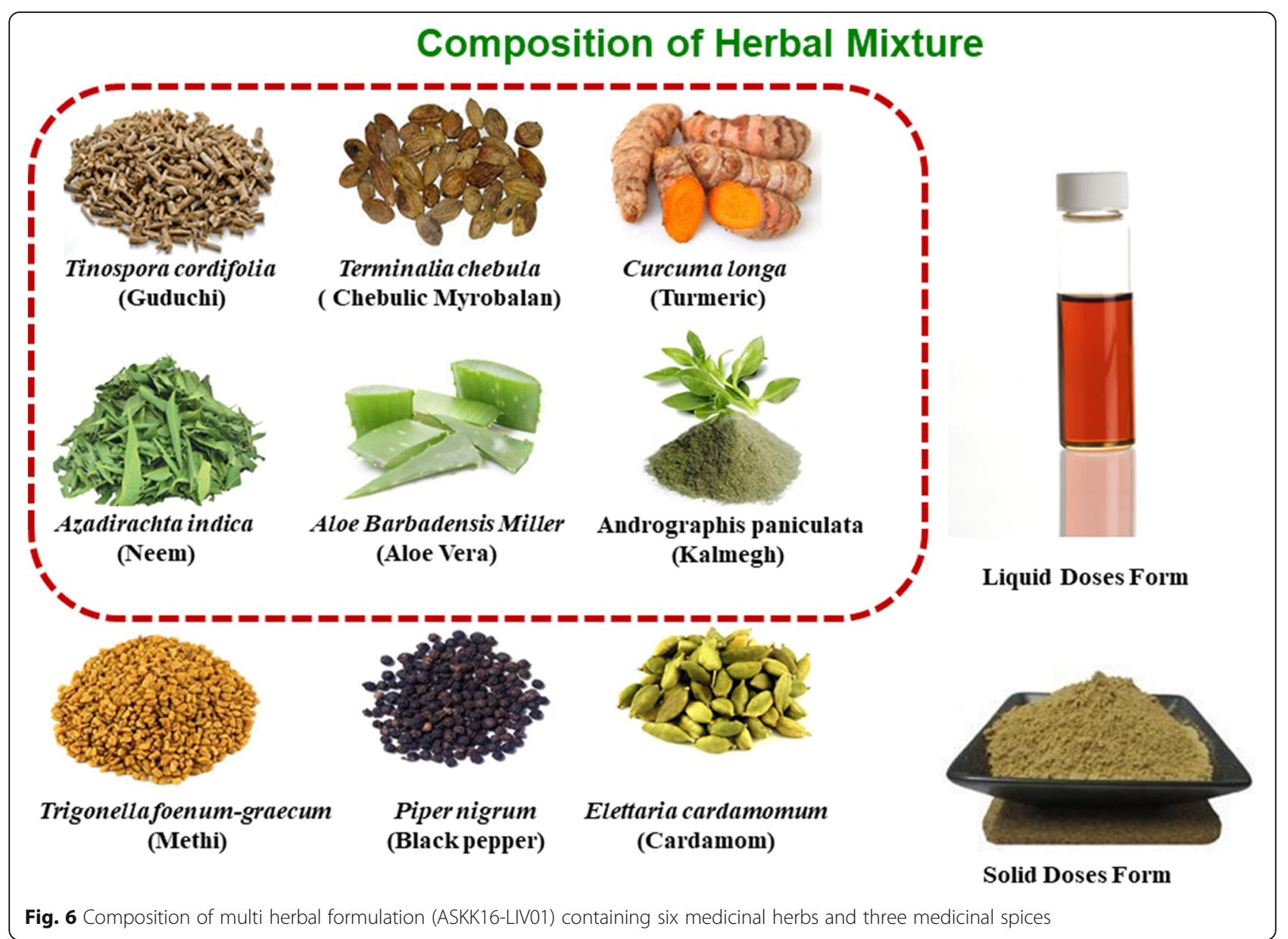

VLDL, and HDL levels of non-enzymatic markers which caused liver damage. This damage is attributed to the higher concentration of alcohol dehydrogenase enzyme which catalyzes alcohol to aldehyde and accumulation of export type proteins due to inhibition of the secretion of the proteins from the liver of alcoholics [75]. Both doses of AKSS16-LIV01 restored the higher level of lipid profile parameters in a dose-dependent manner to normal levels $[74,76,77]$.

It is reported that in cirrhotic mice caused by ethanol produced significantly higher reactive oxygen species (ROS) and malondialdehyde (MDA) as compared to the control animals $[1,2]$. In this study our result also supported the above reports. On the other hand the levels of MDA and ROS content were markedly low in the AKSS16-LIV01 treated group (Table 7). It is predicted that polyphenol, flavonoids, and other essential constituents rich multi herbal formulation (MHF) inhibit lipid peroxidation and reactive oxygen level in experimental mice [78]. During this study, the antioxidant system of liver fibrotic mice was extensively impaired, causing a high level of MDA and ROS. However, in this study higher levels of liver nitrite/nitrate indicating significantly increased production of hepatocellular NO content in response to chronic alcohol administration via induction of inducible nitric oxide synthase (iNOS) [79]. Nitric oxide (NO) and its metabolite i.e. peroxynitrite $\left(\mathrm{ONOO}^{-}\right)$is penetrate the cell membranes through anion channels, which generates nitration of tyrosine and inactivation of biologically important proteins and enzymes [80]. In this study treatment with AKSS16-LIV01 decreased the levels of nitrite/nitrate significantly which was altered by ethanol intoxication. Increasing nitrites/nitrates production in alcoholic mice restored after receiving AKSS16-LIV01, which might be mainly due to inhibition of the hepatic cytosolic iNOS enzyme activity by the newly developed novel multi herbal formulation [81].

Oxidative stress (OS) induced by ethanol intoxication causes liver ailment in alcoholism [82, 83] and produced various health complications. Indian traditional healthcare system is extensively used for a long time to cure liver dysfunctions and augment body's immune system. Two lines of oxidative defense (first and second order) protect cells against oxidative stress. Various scavenging 
enzymes such as SOD, CAT, GPx, and GSH are neutralized and save the cell against oxidative injury. Superoxide ions were scavenged by SOD and catalase converts hydrogen peroxide $\left(\mathrm{H}_{2} \mathrm{O}_{2}\right)$ to water.

In this study chronic administration of alcohol reduced CAT, SOD, GPx as well GSH level in hepatic cell in mice. Oxidative inactivation of the enzyme is the main causes of decreased SOD activity responsible for cell damage. This condition generates massive reactive oxygen species (ROS) and break cellular homeostasis [84]. Reduced glutathione (GSH) is one of the major nonprotein thiol and takes a provital role in coordinating the antioxidant defense process. Normal cell structure \& functions through its detoxification process requires equilibrium of GSH and GPx [85]. Glutathione (GSH) in combination with glutathione peroxidase (GPx) helps to metabolize hydrogen peroxide $\left(\mathrm{H}_{2} \mathrm{O}_{2}\right)$ to water via biochemical pathways, thereby protecting cells against oxidative injury. Administration of our developed multi herbal formulation against ethanol intoxicated mice normalized these essential antioxidant enzymes concentrations in the liver tissue. The formulation thus protects the liver against ethanol-induced redox healing.

TNF- $\alpha$ is a key factor that initiates a cascade of immune responses involving the induction of cytokines after liver damage. In the damaged liver, predominantly Kuffer cells and infiltrating macrophages and neutrophils will produce TNF- $\alpha$. TNF- $\alpha$ plays a dichotomous role in the hepatic tissue, where it not only induces hepatocyte proliferation, apoptosis, and inflammation but also is known to suppress collagen $\alpha 1$ gene expression. Our results showed that the administration of multi herbal formulation (AKSS16-LIV01) with ethanol reduced the level of TNF- $\alpha$ in the liver as compared to ethanol administration alone. This result suggested that AKSS16LIV01 is capable to suppress TNF- $\alpha$ production against ethanol-induced liver damage.

Hepatic stellate cells (HSC) activation was triggered by TGF- $\beta 1$, which was released from Kuffer cells as well as oxidative stress caused by ethanol. TGF- $\beta 1$ regulates the production, degradation, and accumulation of the extracellular matrix (ECM) in liver fibrosis [86]. TGF- $\beta 1$ leads fibrogenesis through the autocrine and paracrine effects of HSC. Our results showed that the administration of AKSS16-LIV01 with ethanol reduced the level of TGF$\beta 1$ in liver tissue as compared with ethanol administration alone. This suggested that the ameliorative effect of AKSS16-LIV01 on ethanol-induced hepatotoxicity was associated with their abilities to inhibit HSC activation by reducing TGF- $\beta 1$ production.

Histopathological examination was an indication of hepatic damages after administration of ethanol. Chronic administration of ethanol developed cellular necrosis, vacuolar degeneration, hyperemia and infiltration of the inflammatory and lymphocyte cells [87-90]. The histopathology of the liver confirmed the protective effect of multi herbal formulation (AKSS16-LIV01). Application of the newly developed unique formulation restored the hepatic damage in mice and inhibits the damaging effect of ethanol. The efficacy of the developed formulation was dipicted by the reduction of livers damages such as necrosis, hyperemia, vacuolar degeneration, and infiltration of the inflammatory cells; the effects were especially evident at the dose of $300 \mathrm{mg} / \mathrm{kg}$. All the above study was compared with standard drug silymarin and it is showed that AKSS16-LIV01 has more potent hepatoprotective effect instead of standard drug.

\section{Conclusion}

The newly developed multi herbal formulation (AKSS16LIV01) has shown protection by ethanol-induced liver injury by ameliorating oxidative stress in mice. The protective action was evidenced by liver histopathological studies, various hepatic enzymes, reduced lipid peroxidation, NO levels, and elevated antioxidant status. Apart from this AKSS16LIV01 can suppress pro-inflammatory cytokines TNF- $\alpha$ and inhibit HSC activation by reducing profibrogenic cytokines TGF- $\beta 1$. The presence of various constituents such as tannins, polyphenols, flavonoids in AKSS16-LIV01 could be contributed to the above mechanism.

\section{Acknowledgments \\ The authors are thankful to Prof. S K Pal, Senior Professor Department of Chemical, Biological \& Macromolecular Sciences S N Bose National Centre for Basic Sciences JD Block, Sector-III Salt Lake City for his guidance and valuable suggestion during this investigation.}

\section{Authors' contributions}

Soumendra Darbar (SD) and Atiskumar Chattopadhyay (AKC): Both authors conceived and designed the experiment. Soumendra Darbar and Srimoyee Saha (SS): Both authors conducted the animal and biochemical experiments, analysed the samples and compiled the data. SD, SS, AKC and Kausikisankar Pramanik (KP): All the authors wrote and revised the manuscript. The author(s) read and approved the final manuscript.

\section{Funding}

There is no funding support for this article.

Availability of data and materials

Research data and materials can be provided on request.

\section{Declarations}

Ethics approval and consent to participate

The animals were maintained according to the guidelines recommended by Committee for the Purpose of Control and Supervision of Experiments on Animals (CPCSEA), Chennai, India which was approved by the Institutional Animal Ethics Committee (IAEC) (Approval No. AEC/PHARM/1503/03/2019 dated 30.11.19). All procedures complied with the Declaration of Helsinki, as revised in 1996.

\section{Consent for publication}

All authors totally agreed for the publication of this research.

Competing interests

The authors declare they have no competing interest. 


\section{Author details}

${ }^{1}$ Faculty of Science, Jadavpur University, Raja S C Mallick Road, Kolkata, West Bengal 700032, India. ${ }^{2}$ Department of Physics, Jadavpur University, Raja S C Mallick Road, West Bengal 700032 Kolkata, India. ${ }^{3}$ Department of Chemistry, Jadavpur University, Raja S C Mallick Road, Kolkata, West Bengal 700032, India.

Received: 3 July 2020 Accepted: 13 September 2021

Published online: 12 October 2021

\section{References}

1. Adhikari A, Polley N, Darbar S, Bagchi D, Pal SK. Citrate functionalized $\mathrm{Mn}_{3} \mathrm{O}_{4}$ in nanotherapy of hepatic fibrosis by oral administration. Future Sci OA. 2016;2(4):1-21. https://doi.org/10.4155/fsoa-2016-0029.

2. Adhikari A, Polley N, Darbar S, Pal SK. Therapeutic potential of surface functionalized $\mathrm{Mn}_{3} \mathrm{O}_{4}$ nanoparticles against chronic liver diseases in murine model. Mater Focus. 2017;6(3):280-9. https://doi.org/10.1166/ma t.2017.1403.

3. Cebral E, Lasserre A, Rettori V, Gimeno MAD. Impaired mouse fertilization by low chronic alcohol treatment. Alcohol Alcohol. 1997;32(5):563-72. https:// doi.org/10.1093/oxfordjournals.alcalc.a008297.

4. Loguercio C, Piscopo P, Guerriero C, Girolamo VD, Disalvo D, Del Vecchio BC. Effect of alcohol abuse and glutathione administration on the circulating levels of glutathione and on antipyrine metabolism in patients with alcoholic liver cirrhosis. Scand J Clin Lab Invest. 1996;56(5):441-7. https://doi.org/10.3109/00365519609088799.

5. Polley N, Saha S, Adhikari A, Banerjee S, Darbar S, Das S, et al. Safe and symptomatic medicinal use of surface-functionalized $\mathrm{Mn}_{3} \mathrm{O}_{4}$ nanoparticles for hyperbilirubinemia treatment in mice. Nanomedicine. 2015;10(15):234963. https://doi.org/10.2217/nnm.15.83.

6. Das SK, Vasudevan D. Alcohol-induced oxidative stress. Life Sci. 2007:81(3): 177-87. https://doi.org/10.1016/j.lfs.2007.05.005.

7. Seitz HK, Mueller S. Alcoholic liver disease. Int Clin Hepatol. 2010:1111-51. https://doi.org/10.1007/978-3-642-04519-6_34.

8. Manjunatha B, Mankani K, Mukunda S, Divakara R, Sridar B, Paul K. Antioxidant and hepato protective effect of Myristica malabarica seed aril extracts on carbon tetrachloride induced hepatic damage. Glob J Biotech Biochem. 2011;6(1):25-30.

9. Chitra K, Sajitha R. Effect of bisphenol-a on the antioxidant defense system and its impact on the activity of succinate dehydrogenase in the gill of freshwater fish, Oreochromis mossambicus. J Cell Tissu Res. 2014;14(2):4219-26.

10. Sánchez-Valle V, Chavez-Tapia NC, Uribe M, Méndez-Sánchez N. Role of oxidative stress and molecular changes in liver fibrosis: a review. Curr Med Chem. 2012;19(28):4850-60. https://doi.org/10.2174/092986712803341520.

11. Li A-N, Li S, Zhang Y-J, Xu X-R, Chen Y-M, Li H-B. Resources and biological activities of natural polyphenols. Nutrients. 2014;6(12):6020-47. https://doi. org/10.3390/nu6126020.

12. Feng $Y$, Wang $N$, Ye X, Li H, Feng Y, Cheung F, et al. Hepatoprotective effect and its possible mechanism of Coptidis rhizoma aqueous extract on carbon tetrachloride-induced chronic liver hepatotoxicity in rats. J Ethnopharmacol. 2011;138(3):683-90. https://doi.org/10.1016/j.jep.2011.09.032

13. Rodenburg LA, Guo J, Du S, Cavallo GJ. Evidence for unique and ubiquitous environmental sources of 3, 3'-dichlorobiphenyl (PCB 11). Environ Sci Technol. 2010;44(8):2816-21. https://doi.org/10.1021/es901155h.

14. Norström K, Czub G, McLachlan MS, Hu D, Thorne PS, Hornbuckle KC. External exposure and bioaccumulation of PCBs in humans living in a contaminated urban environment. Environ Int. 2010;36(8):855-61. https:// doi.org/10.1016/j.envint.2009.03.005.

15. Kabuto H, Amakawa M, Shishibori T. Exposure to bisphenol A during embryonic/fetal life and infancy increases oxidative injury and causes underdevelopment of the brain and testis in mice. Life Sci. 2004;74(24): 2931-40. https://doi.org/10.1016/j.lfs.2003.07.060.

16. Chanda S, Dave R. In vitro models for antioxidant activity evaluation and some medicinal plants possessing antioxidant properties: an overview. Afr J Microbiol Res. 2009;3(13):981-96.

17. McGrath L, McGleenon B, Brennan S, McColl D, Mcllroy S, Passmore A Increased oxidative stress in Alzheimer's disease as assessed with 4hydroxynonenal but not malondialdehyde. Qjm. 2001;94(9):485-90. https:// doi.org/10.1093/qjmed/94.9.485.
18. Adhikari A, Mondal S, Darbar S, Pal SK. Role of nanomedicine in redox mediated healing at molecular level. Biomol Concepts. 2019;10(1):160-74. https://doi.org/10.1515/bmc-2019-0019.

19. Darbar S, Bhattacharya A, Chattopadhyay S. Ameliorative effect of Livina, a polyherbal preparation on diclofenac-induced liver injury: a comparison with Silymarin. J Pharm Res. 2010;3(12):2794-8.

20. Bello IA, Ndukwe Gl, Audu OT, Habila JD. A bioactive flavonoid from Pavetta crassipes K. Schum Org Med Chem Lett. 2011;1(1):1-5. https://doi.org/10.11 86/2191-2858-1-14.

21. Thompson M, Jaiswal Y, Wang I, Williams L. Hepatotoxicity: treatment, causes and applications of medicinal plants as therapeutic agents. J Phytopharmacol. 2017;6(3):186-93.

22. De S, Suresh R, Babu AMSS, Aneela S. In-vivo hepatoprotective activity of methanolic extracts of Sphaeranthus amaranthoides and Oldenlandia umbellate. Pharmacogn J. 2017;9(1):98-101. https://doi.org/10.5530/pj.2017.1.16.

23. Darbar S, Saha S, Pramanik K, Chattopadhyay A. Preliminary acute oral toxicity study of a newly developed herbal formulation. World J Pharm Res. 2018;7:924-30.

24. Darbar S, Saha S, Pramanik K, Chattopadhyay A. Preliminary assessment of acute and 28-day repeated dose oral toxicity of a newly developed herbal mixture on experimental animal. Ind J Pharm Edu Res. 2000;54(1):135-42. https://doi.org/10.5530/ijper.54.1.16.

25. Johari $H$, Sharifi E, Ansari N, Hosseini M, Amiri F. Effect of hydro alcoholic ginger extracts on the body weight, testis weight and spermatogenesis in male rats undergoing chemotherapy with cyclophosphamide. SSU J. 2010; 17(5):365-74.

26. Da-Cheng HA, Xiao-Jie GU, Pei-Gen XI, Yong PE. Phytochemical and biological research of fritillaria medicine resources. Chin J Nat Med. 2013; 11(4):330-44.

27. Maregesi SM, Hermans N, Dhooghe L, Cimanga K, Ferreira D, Pannecouque $C$, et al. Phytochemical and biological investigations of Elaeodendron schlechteranum. J Ethnopharmacol. 2010;129(3):319-26. https://doi.org/10.1 016/j.jep.2010.03.034.

28. Waniska RD, Hugo LF, Rooney LW. Practical methods to determine the presence of tannins in sorghum. J Appl Poult Res. 1992;1(1):122-8. https:// doi.org/10.1093/japr/1.1.122.

29. Sinha SK, Dogra JV. A survey of the plants of Bhagalpur and Santhal Pargana for saponin, flavonoids and alkaloids. Int J Crude Drug Res. 1985: 23(2):77-86. https://doi.org/10.3109/13880208509069006.

30. Trevisan G, Rossato MF, Walker Cl, Klafke JZ, Rosa F, Oliveira SM, et al. Identification of the plant steroid a-spinasterol as a novel transient receptor potential vanilloid 1 antagonist with antinociceptive properties. J Pharmacol Exp Ther. 2012;343(2):258-69. https://doi.org/10.1124/jpet.112.195909.

31. Scortichini M, Rossi MP. Preliminary in vitro evaluation of the antimicrobial activity of terpenes and terpenoids towards Erwinia amylovora (Burrill). J Appl Bacteriol. 1991;71(2):109-12. https://doi.org/10.1111/j.1365-2672.1991.tb02963.x.

32. Ratty AK, Das NP. Effects of flavonoids on nonenzymatic lipid peroxidation: structure-activity relationship. Biochem Med Metab Biol. 1988;39(1):69. https://doi.org/10.1016/0885-4505(88)90060-6.

33. Hussain HS, Deeni YY. Plants in Kano ethnomedicine; screening for antimicrobial activity and alkaloids. Int J Pharmacogn. 1991;29(1):51-6. https://doi.org/10.3109/13880209109082849.

34. Dar Al, Masar G, Jadhaw V, Bansal SK, Saxena RC. Isolation and structural elucidation of the novel flavone glycoside from Feronia limonia L. J Pharm Res. 2013;7(8):697-704. https://doi.org/10.1016/j.jopr.2013.04.058.

35. Arnold T, Appel H, Patel V, Stocum E, Kavalier A, Schultz J. Carbohydrate translocation determines the phenolic content of Populus foliage: a test of the sink-source model of plant defense. New Phytol. 2004;164(1):157-64. https://doi.org/10.1111/j.1469-8137.2004.01157.x.

36. Panteghini M. Aspartate aminotransferase isoenzymes. Clin Biochem. 1990; 23(4):311-9. https://doi.org/10.1016/0009-9120(90)80062-N.

37. Valentine BA, Blue JT, Shelley SM, Cooper BJ. Increased serum alanine aminotransferase activity associated with muscle necrosis in the dog. J Vet Intern Med. 1990;4(3):140-3. https://doi.org/10.1111/j.1939-1676.1990. tb00886.x.

38. Gomez B Jr, Ardakani S, Ju J, Jenkins D, Cerelli MJ, Daniloff GY, et al. Monoclonal antibody assay for measuring bone-specific alkaline phosphatase activity in serum. Clin Chem. 1995;41(11):1560-6. https://doi. org/10.1093/clinchem/41.11.1560.

39. Saely CH, Vonbank A, Rein P, Woess M, Beer S, Aczel S, et al. Alanine aminotransferase and gamma-glutamyl transferase are associated with the 
metabolic syndrome but not with angiographically determined coronary atherosclerosis. Clin Chim Acta. 2008;397(1-2):82-6. https://doi.org/10.1016/j. cca.2008.07.024.

40. Kingsley GR. The determination of serum total protein, albumin, and globulin by the biuret reaction. J Biol Chem. 1939;131(1):197-200. https:// doi.org/10.1016/S0021-9258(18)73494-7.

41. Garber CC. Jendrassik--Grof analysis for total and direct bilirubin in serum with a centrifugal analyzer. Clin Chem. 1981;27(8):1410-6. https://doi.org/1 0.1093/clinchem/27.8.1410

42. Kashyap M, Hynd B, Robinson K. A rapid and simple method for measurement of total protein in very low density lipoproteins by the Lowry assay. J Lipid Res. 1980;21(4):491-5. https://doi.org/10.1016/S0022-2275(20)39803-5.

43. Zlatkis A, Zak B, Boyle AJ. A new method for the direct determination of serum cholesterol. J Lab Clin Med. 1953;41(3):486-92.

44. Van Handel E, Zilversmit DB. Micromethod for the direct determination of serum triglycerides. J Lab Clin Med. 1957;50(1):152-7.

45. Takayama M, Itoh S, Nagasaki T, Tanimizu I. A new enzymatic method for determination of serum choline-containing phospholipids. Clin Chim Acta. 1977:79(1):93-8. https://doi.org/10.1016/0009-8981(77)90465-X.

46. Shimizu S, Tani Y, Yamada H, Tabata M, Murachi T. Enzymatic determination of serum-free fatty acids: a colorimetric method. Anal Biochem. 1980;107(1): 193-8. https://doi.org/10.1016/0003-2697(80)90511-4.

47. Liu KZ, Shi M, Man A, Dembinski TC, Shaw RA. Quantitative determination of serum LDL cholesterol by near-infrared spectroscopy. Vib Spectrosc. 2005; 38(1-2):203-8. https://doi.org/10.1016/j.vibspec.2005.04.005.

48. Berchtold P, Berger M, Jörgens V, Daweke C, Chantelau E. HDL-cholesterol levels in obesity. Int J Obes. 1981;5:1-0.

49. Hashimoto S. A new spectrophotometric assay method of xanthine oxidase in crude tissue homogenate. Anal Biochem. 1974;62(2):426-35. https://doi. org/10.1016/0003-2697(74)90175-4

50. Ohkawa H, Ohishi N, Yagi K. Assay for lipid peroxides in animal tissues by thiobarbituric acid reaction. Anal Biochem. 1979:95(2):351-8. https://doi. org/10.1016/0003-2697(79)90738-3.

51. Chattopadhyay A, Darbar S, Saha S, Karmakar P. Effects of alprazolam administration on the vital organs of adult wister albino rats, biochemical and toxicological studies. Ind J Pharm Edu Res. 2019;53(1):127-32. https:// doi.org/10.5530/ijper.53.1.17.

52. Misra HP, Fridovich I. The role of superoxide anion in the autoxidation of epinephrine and a simple assay for superoxide dismutase. J Biol Chem. 1972;247(10):3170-5. https://doi.org/10.1016/S0021-9258(19)45228-9.

53. Santos LF, Freitas RL, Xavier SM, Saldanha GB, Freitas RM. Neuroprotective actions of vitamin $C$ related to decreased lipid peroxidation and increased catalase activity in adult rats after pilocarpine-induced seizures. Pharmacol Biochem Behav. 2008;89(1):1-5. https://doi.org/10.1016/j.pbb.2007.10.007.

54. Mkoji G, Smith J, Prichard R. Antioxidant systems in Schistosoma mansoni: correlation between susceptibility to oxidant killing and the levels of scavengers of hydrogen peroxide and oxygen free radicals. Int J Parasitol. 1988;18(5):661-6. https://doi.org/10.1016/0020-7519(88)90101-4.

55. Ellman GL. Tissue sulfhydryl groups. Arch Biochem Biophys. 1959;82(1):70-7. https://doi.org/10.1016/0003-9861(59)90090-6.

56. Hafeman D, Sunde R, Hoekstra W. Effect of dietary selenium on erythrocyte and liver glutathione peroxidase in the rat. J Nutr. 1974;104(5):580-7. https://doi.org/10.1093/jn/104.5.580.

57. Kienast K, Knorst M, Müller-Quernheim J, Ferlinz R. Modulation of IL-1 $\beta, I L-6$, IL-8, TNF- $a$, and TGF- $\beta$ secretions by alveolar macrophages under $\mathrm{NO}_{2}$ exposure. Lung. 1996;174(1):57-67.

58. Li Y, Li N, Yu X, Huang $K$, Zheng T, Cheng $X$, et al. Hematoxylin and eosin staining of intact tissues via delipidation and ultrasound. Sci Rep. 2018;8(1): 1-8. https://doi.org/10.1038/s41598-018-30755-5.

59. Malkusch W, Rehn B, Bruch J. Advantages of Sirius red staining for quantitative morphometric collagen measurements in lungs. Exp Lung Res. 1995:21(1):67-77. https://doi.org/10.3109/01902149509031745.

60. Room R, Babor T, Rehm J. Alcohol and public health. Lancet. 2005;365(9458): 519-30. https://doi.org/10.1016/S0140-6736(05)17870-2.

61. Cahill A, Cunningham CC, Adachi M, Ishii H, Bailey SM, Fromenty B, et al. Effects of alcohol and oxidative stress on liver pathology: the role of the mitochondrion. Alcohol Clin Exp Res. 2002;26(6):907-15. https://doi.org/1 0.1111/j.1530-0277.2002.tb02621.x

62. Hoek JB, Pastorino JG. Cellular signaling mechanisms in alcohol-induced liver damage. Semin Liver Dis. 2004;24(3):257-72. https://doi.org/10.1055/s-2 004-832939.
63. Lieber CS. Role of oxidative stress and antioxidant therapy in alcoholic and nonalcoholic liver diseases. Adv pharmacol. 1996;38:601-28.

64. Oyama Y, Sakai H, Arata T, Okano Y, Akaike N, Sakai K, et al. Cytotoxic effects of methanol, formaldehyde, and formate on dissociated rat thymocytes: a possibility of aspartame toxicity. Cell Biol Toxicol. 2002;18(1):43-50. https:// doi.org/10.1023/A:1014419229301.

65. Fridovich I. Superoxide dismutases. Annu Rev Biochem. 1975;44(1):147-59. https://doi.org/10.1146/annurev.bi.44.070175.001051.

66. Raj A, Praveen KV, Varghese S, Mukkadan J, Joseph P. Biochemical effects of feeding soft drink and ethanol. Ind J Exp Biol. 2009;47(05):333-7.

67. Das SK, Dhanya L, Varadhan S, Mukherjee S, Vasudevan D. Effects of chronic ethanol consumption in blood: a time dependent study on rat. Ind J Clin Biochem. 2009;24(3):301-6. https://doi.org/10.1007/s12291-009-0056-4.

68. Deb A. Fundamental of biochemistry. 9th ed. Calcutta: New central book agency (p) Itd; 1998

69. Gujrati V, Patel N, Rao VN, Nandakumar K, Gouda T, Shalam M, et al. Hepatoprotective activity of alcoholic and aqueous extracts of leaves of Tylophora indica (Linn.) in rats. Ind J Pharmacol. 2007;39(1):43-7.

70. Dinu D, Nechifor MT, Movileanu L. Ethanol induced alterations of the antioxidant defense system in rat kidney. J Biochem Mol Toxicol. 2006;19(6): 386-95. https://doi.org/10.1002/jbt.20101.

71. Yang CS, Landau JM, Huang MT, Newmark HL. Inhibition of carcinogenesis by dietary polyphenolic compounds. Annu Rev Nutr. 2001;21(1):381-06. https://doi.org/10.1146/annurev.nutr.21.1.381.

72. Dahiru D, Obidoa O. Pretreatment of albino rats with aqueous leaf extract of Ziziphus mauritiana protects against alcohol-induced liver damage. Trop J Pharm Res. 2007;6(2):705-10. https://doi.org/10.4314/tjpr.v6i2.14649.

73. Halliwell B, Gutteridge JM. Oxygen free radicals and iron in relation to biology and medicine: some problems and concepts. Arch Biochem Biophys. 1986;246(2):501-14. https://doi.org/10.1016/00039861(86)90305-X

74. Nordmann R, Ribière $\mathrm{C}$, Rouach $\mathrm{H}$. Implication of free radical mechanisms in ethanol-induced cellular injury. Free Radic Biol Med. 1992;12(3):219-40. https://doi.org/10.1016/0891-5849(92)90030-K

75. Baraona E, Lieber CS. Effects of alcohol on hepatic transport of proteins. Annu Rev Med. 1982;33(1):281-92. https://doi.org/10.1146/annurev.me.33.02 0182.001433 .

76. Kandhare AD, Raygude KS, Ghosh P, Bodhankar SL. The ameliorative effect of fisetin, a bioflavonoid, on ethanol-induced and pylorus ligation-induced gastric ulcer in rats. Int J Green Pharm. 2011:5(3):236-43.

77. Shaw S, Jayatilleke E, Ross W, Gordon E, Lieber C. Ethanol-induced lipid peroxidation: potentiation by long-term alcohol feeding and attenuation by methionine. J Lab Clin Med. 1981;98(3):417-24.

78. Husain K, Ortiz MV, Lalla J. Physical training ameliorates chronic alcoholinduced hypertension and aortic reactivity in rats. Alcohol Alcohol. 2006 41(3):247-53. https://doi.org/10.1093/alcalc/agl005.

79. Saoudi M, Jebahi S, Jamoussi K, Salah GB, Kallel C, Feki AE. Haematological and biochemical toxicity induced by methanol in rats: ameliorative effects of Opuntia vulgaris fruit extract. Hum Exp Toxicol. 2011;30(12):1963-71. https://doi.org/10.1177/0960327111403175.

80. Zhou Z, Sun X, Kang YJ. Metallothionein protection against alcoholic liver injury through inhibition of oxidative stress. Exp Biol Med. 2002;227(3):21422. https://doi.org/10.1177/153537020222700310.

81. Wang JF, Greenberg SS, Spitzer JJ. Chronic alcohol administration stimulates nitric oxide formation in the rat liver with or without pretreatment by lipopolysaccharide. Alcohol Clin Exp Res. 1995;19(2):387-93. https://doi.org/1 0.1111/j.1530-0277.1995.tb01520.x.

82. Li S, Tan H-Y, Wang N, Zhang Z-J, Lao L, Wong C-W, et al. The role of oxidative stress and antioxidants in liver diseases. Int J Mol Sci. 2015;16(11): 26087-124. https://doi.org/10.3390/ijms161125942.

83. Pacher P, Beckman JS, Liaudet L. Nitric oxide and peroxynitrite in health and disease. Physiol Rev. 2007;87(1):315-24. https://doi.org/10.1152/physrev.0002 9.2006 .

84. Yokozawa T, Kim HY, Kim HJ, Okubo T, Chu D-C, Juneja LR. Amla (Emblica officinalis Gaertn.) prevents dyslipidaemia and oxidative stress in the ageing process. Br J Nutr. 2007:97(6):1187-95. https://doi.org/10.1017/S0007114 507691971

85. Pigeolet $\mathrm{E}$, Corbisier $\mathrm{P}$, Houbion A, Lambert D, Michiels C, Raes $\mathrm{M}$, et al. Glutathione peroxidase, superoxide dismutase, and catalase inactivation by peroxides and oxygen derived free radicals. Mech Ageing Dev. 1990;51(3): 283-97. https://doi.org/10.1016/0047-6374(90)90078-T. 
86. Wilce MC, Parker MW. Structure and function of glutathione S-transferases. Biochem Biophys Acta Protein Struct Mol Enzymol. 1994;1205(1):1-18. https://doi.org/10.1016/0167-4838(94)90086-8.

87. Hayes JD, Pulford DJ. The glut athione S-transferase supergene family: regulation of GST and the contribution of the Isoenzymes to cancer chemoprotection and drug resistance part I. Crit Rev Biochem Mol Biol. 1995;30(6):445-20. https://doi.org/10.3109/10409239509083491.

88. Ålin P, Danielson UH, Mannervik B. 4-Hydroxyalk-2-enals are substrates for glutathione transferase. FEBS Lett. 1985;179(2):267-70. https://doi.org/10.101 6/0014-5793(85)80532-9.

89. Schwabe RF, Brenner DA. Mechanisms of liver injury. I. TNF-a-induced liver injury: role of IKK, JNK, and ROS pathways. Am J Physiol Gastrointest Liver Physiol. 2006;290(4):G583-9. https://doi.org/10.1152/ajpgi.00422.2005.

90. Hong L, Shejiao D, Fenrong C, Gang Z, Lei D. Periostin down-regulation attenuates the pro-fibrogenic response of hepatic stellate cells induced by TGF- $\beta 1$. J Cell Mol Med. 2015;19(10):2462-8. https://doi.org/10.1111/ jcmm.12636.

\section{Publisher's Note}

Springer Nature remains neutral with regard to jurisdictional claims in published maps and institutional affiliations.

\section{Submit your manuscript to a SpringerOpen ${ }^{\circ}$ journal and benefit from:}

- Convenient online submission

- Rigorous peer review

- Open access: articles freely available online

High visibility within the field

- Retaining the copyright to your article

Submit your next manuscript at $\boldsymbol{\nabla}$ springeropen.com 